Portland State University

PDXScholar

Summer 2018

\title{
The Mountain of a Thousand Holes: Shipwreck Traditions and Treasure Hunting on Oregon's North Coast
}

\author{
Cameron La Follette \\ Oregon Coast Alliance \\ Dennis Griffin \\ Oregon State Historic Preservation Office \\ Douglas Deur \\ Portland State University, deur@pdx.edu
}

Follow this and additional works at: https://pdxscholar.library.pdx.edu/anth_fac

Part of the Archaeological Anthropology Commons, and the Biological and Physical Anthropology Commons

Let us know how access to this document benefits you.

\section{Citation Details}

Cameron La Follette, Dennis Griffin, \& Douglas Deur. (2018). The Mountain of a Thousand Holes:

Shipwreck Traditions and Treasure Hunting on Oregon's North Coast. Oregon Historical Quarterly, 119(2), 282-313.

This Article is brought to you for free and open access. It has been accepted for inclusion in Anthropology Faculty Publications and Presentations by an authorized administrator of PDXScholar. Please contact us if we can make this document more accessible: pdxscholar@pdx.edu. 


\title{
The Mountain of a Thousand Holes
}

\author{
Shipwreck Traditions and Treasure Hunting on \\ Oregon's North Coast
}

\section{CAMERON LA FOLLETTE, DENNIS GRIFFIN, AND DOUGLAS DEUR}

EURO-AMERICANS in coastal communities conflated and amplified Native American oral traditions of shipwrecks in Tillamook County, increasingly focusing the stories on buried treasure. This focus led to a trickle, and then a procession, of treasure-seekers visiting the northern Oregon coast, reaching full crescendo by the mid to late twentieth century. The seekers' theories ranged from the fairly straightforward to the wildly carnivalesque, with many bizarre permutations. Neahkahnie Mountain and its beaches became the premier treasure-hunting sites in Oregon, based on the mountain's prominence in popular lore, linked to unverified stories about the wreck of a Spanish ship. From 1967 to 1999, Oregon had a formal "Treasure Trove" permit process to regulate treasure-hunting on state-owned public lands; 93 percent of the applications requested access to the Neahkahnie area. ${ }^{1}$

The basic outlines of the legends contributing to Neahkahnie's reputation as Oregon's treasure-seeking haven are fairly consistent. Three elements were commonly conflated in local oral tradition: the wreck of a Spanish galleon, now thanks to archaeological analysis thought to be the Santo Cristo de Burgos of 1693, on Nehalem Spit; the tale, loosely based on local Native oral traditions, of sailors coming ashore from a European ship and burying a large box with unspecified contents on the flanks of Neahkahnie Mountain, before returning to the ship and sailing away; and the discovery of a number of stones on Neahkahnie Mountain and at its base with strange dots, lines, markings, letters, and occasionally, and words. ${ }^{2}$

Nehalem-Tillamook people, like those of other coastal Native communities, held codes and concepts of property that extended to valuable items drifting ashore. Large drift logs, beached whales, and other finds of major value on the 


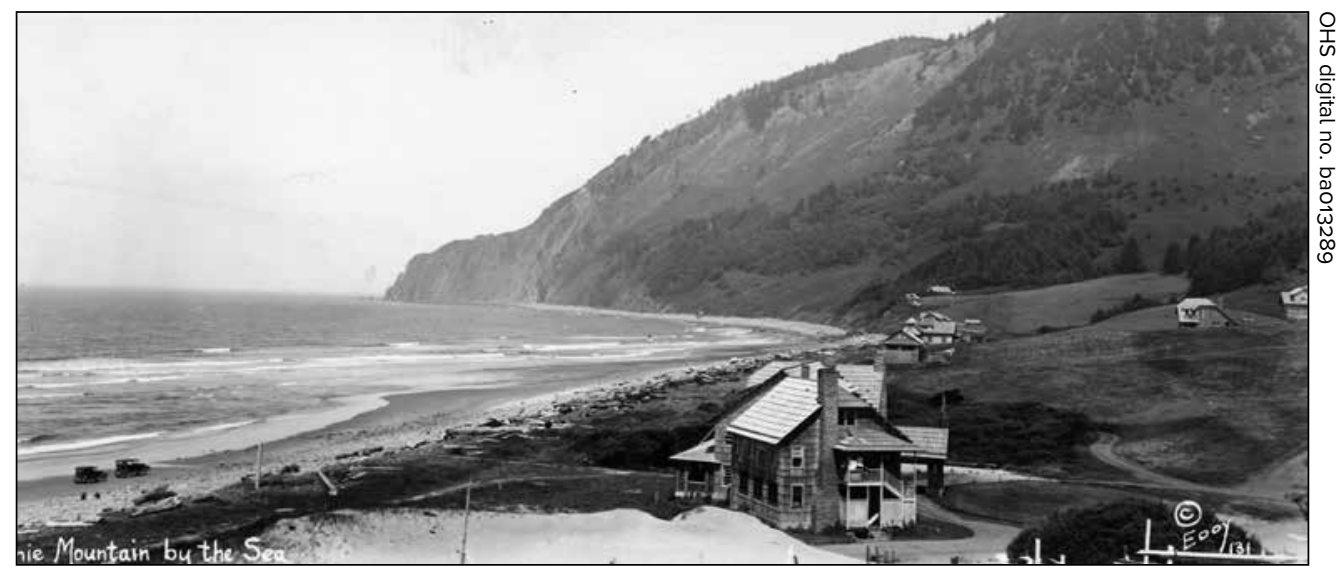

NEAHKAHNIE MOUNTAIN and the beaches below have been Oregon's premier treasurehunting sites for nearly two centuries, based on fevered speculation and a tangle of shipwreck lore. Treasure seeking and excavations have occurred both on private lands and, as recently as 1989, on public lands. Today, Neahkahnie is part of Oswald West State Park.

strand fell to those communities who inhabited and held claim to the point of landfall, and shipwrecks seem to have been apportioned likewise. Materials such as metals might be salvaged, creating new objects for local use or for barter within extensive regional trading networks. ${ }^{3}$ By contrast, Euro-American treasure-trove laws centered directly on individual opportunities for wealth by finding objects of value. Rumors of treasure-seeking treks to Neahkahnie Mountain appeared almost immediately after Euro-American arrival on the north coast, attracting both British and American fur traders.

Mary Gerritse, an early-twentieth-century north coast postmistress, noted that "[an] old Indian, years ago said his father told him that one of the Astors for whom Astoria was named took a long train of pack horses from Astoria into the Nehalem country and brought them back heavily loaded with something. Perhaps that accounts for the fact that no later searcher has been successful." 4 The Astor Expedition founded the fur-trading fort in 1811 and abandoned it two years later. ${ }^{5}$ On the basis of unspecified oral history, early Oregon historian Samuel Clarke reported that Thomas McKay, stepson of Dr. John McLoughlin, heard of the treasure, while fur-trapping, from "an ancient crone, who told him that when a child she witnessed the coming ashore of the Spaniards who buried the treasure." ${ }^{6} \mathrm{He}$ apparently searched for it; whether he found it is inconclusive, although officials of the Hudson's Bay Company, for whom he worked, questioned him closely. He denied having found any treasure. Yet, Clarke points out, "he was a generous fellow and always had money to spend 


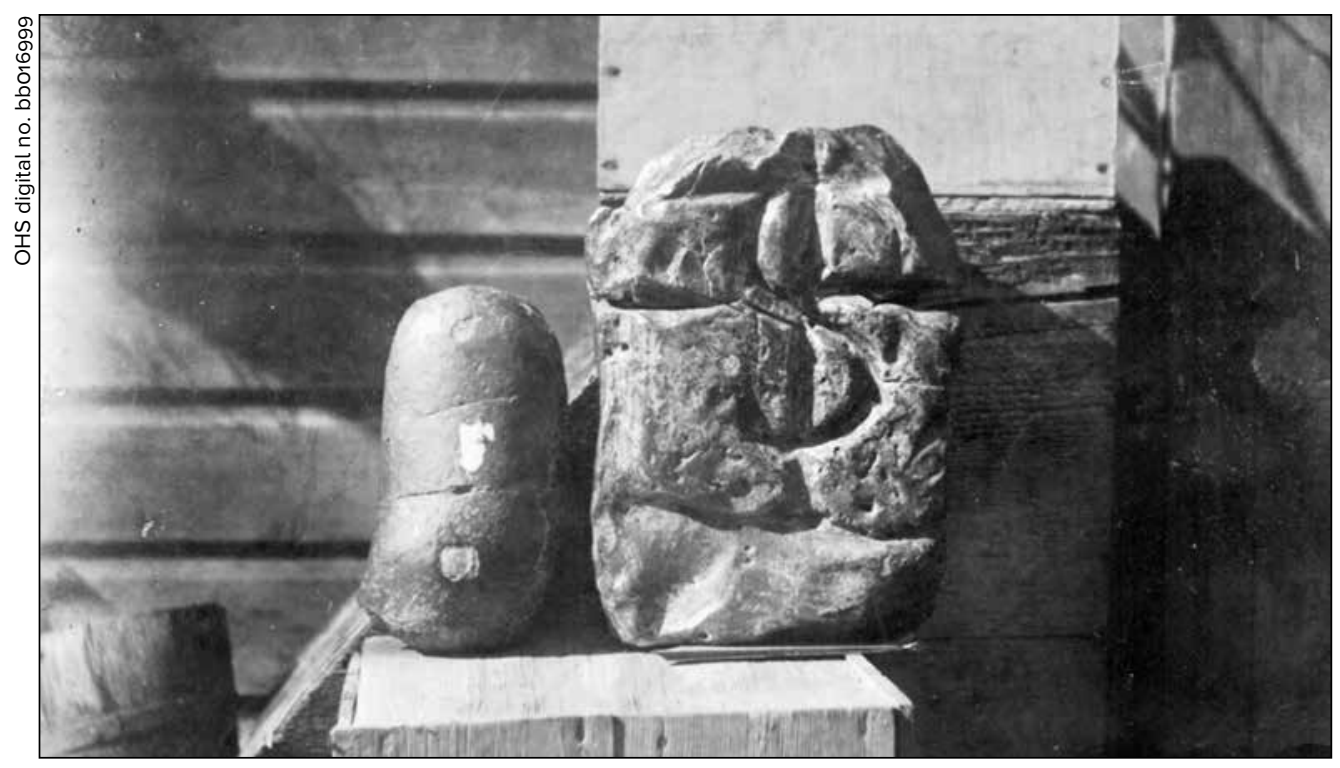

PICTURED HERE on the right is one of the beeswax blocks, with Spanish shipper's mark still visible, found in the vicinity of the Nehalem Bay sandspit, probably in the late nineteenth or early twentieth century. On the left is also a piece of beeswax without a shipper's mark.

and to give away, so much so, that when he afterwards settled on French Prairie, he lived so well and was so liberal to all in need, that people believed that he had surely found that treasure." 7 Whether other such treasure-seeking treks as described here occurred, and whether they resulted in significant recoveries, remains speculative.

John Hobson, who came to the Clatsop Plains in 1843, learned from local Native oral tradition of an abundance of beeswax eroding from nearby beaches, often in large blocks, from an old shipwreck. Solomon H. Smith, a Clatsop Plains pioneer, farmer, and storekeeper, and husband of Celiast, a prominent Clatsop woman, was also well aware of Native American shipwreck stories. Smith's father-in-law was Chief Coboway, the principal Native American host to the Lewis and Clark Expedition during its 1805-1806 stay at Fort Clatsop. ${ }^{8}$ In 1848 , Hobson and Smith traveled together to the Nehalem River mouth with an unnamed Native guide in pursuit of cargo from the wrecked Hudson's Bay Company bark Vancouver - but also to "find out what we could from the old Indians about the wax and money vessels." Hobson heard accounts mentioning gold and silver coins, suggesting that buried treasure may have been linked to the wreck from which the beeswax came, or one nearby. The Indians told tales of another ship anchored near the shore. They said people from it brought a chest onto "Necarney Mountain," 
and placed sacks of money into it, as well as the corpse of a man they killed. Over the chest they placed a marked stone. ${ }^{9}$ Finding no coins, marked rocks showing the treasure's location, or any other evidence, Hobson concluded that the lore of shipwrecked treasure was unreliable. ${ }^{10}$

Treasure-hunting excited many early Euro-American settlers and visitors to Neahkahnie, but none more than Hiram Smith, a surveyor and early settler who took a land claim out in 1853 in what is now Bay City. He reported discovery of some of the enigmatic marked stones that became central to local lore. By Smith's time, north coast residents commonly described the stones as treasure maps left by mariners, castaways, or explorers whom they believed had hidden treasure in the Neahkahnie area. Smith began to actively dig for treasure on the mountain beginning around $1865 .{ }^{11}$ He passed on his knowledge and fascination to his son, Patrick Smith, who continued to search for forty years, usually with his protégé Charlie Pike. ${ }^{12}$ The work of treasure-seekers such as the Smiths and Pike ultimately became integral to the oral traditions of Neahkahnie Mountain and, in turn, inspired a future generation of treasure hunters to seek their fortunes, always unsuccessfully, on Oregon's north coast.

\section{A COMPLICATING ELEMENT: THE NEAHKAHNIE MARKED STONES}

Adding considerable weight to the Neahkahnie treasure-hunting legend are several marked stones found on or near the southwestern face of the mountain. These puzzling stones have yet to be deciphered, and divergent theories abound as to their provenance and purpose. One popular historian noted that John Hobson, the first known Euro-American treasure seeker, mentioned a "marked rock" and hinted at oral traditions of the existence of others as early as 1848 - well before the later claimants to their "discovery."13

Some sources contend that Hiram Smith found two stones chiseled with letters and symbols, probably in the late 1850 s, and that his account was key in bringing the stones to the attention of north coast residents. ${ }^{14}$ In 1858, F.H. Shepherd may have been the first to formally report a marked stone, which was very large. In 1895, he made a sketch of it. It is usually called the "W-rock" for one of the letter markings. Another, smaller, marked stone (the "BKS rock") was found nearby and can be seen next to the W-rock in later photographs. ${ }^{15}$ In 1865, Manzanita homesteader Will Snyder plowed a meadow near the beach and found a boulder with designs similar to those reported by Smith and Shepherd. Homesteader William Batterson found several more marked stones in $1880 .{ }^{16}$ As Samuel Cotton observed, "Taking all these strange markings together there is no wonder men have drawn the conclusion that they can solve the mystery of where the treasure is buried." 17

Popular writer Thomas $\mathrm{H}$. Rogers, from McMinnville, also wrote of the stones in 1900, having seen four of them in a pasture that he visited with 
Pat Smith. Rogers noted that some had been moved around and disfigured by unknown people, in an effort to mislead Smith in his prolonged treasure searches. Rogers reported that Smith was undeterred in following the legend that a box of gold was buried in the vicinity, but he did not think the marked stones related to the treasure he was seeking. ${ }^{18}$

Widely interpreted as a marker stone, the W-rock was apparently moved at least twice from where it was found, either for promotional purposes or to accommodate building projects. Beginning in 1907, Portland entrepreneur Samuel G. Reed developed the settlement of Neahkahnie on the sloping hillside at the foot of the mountain. The showcase of his development was the Neahkahnie Tavern, built in 1912. Reed sometimes struggled to fill the hotel with guests in what was, at that time, a far-flung corner of the Oregon coast. Reed promoted the marked stones and the likelihood of treasure on Neahkahnie, even providing picks and shovels so his guests could dig for treasure. ${ }^{19}$

A second hypothesis about the marked stones, controversial but enduring, interprets them as survey markers placed by Sir Francis Drake in his circumnavigation of the world. As published accounts attest, Drake sailed some distance up the North American coast in 1579, spending six weeks in a bay careening his ship, the Golden Hind. Crude maps, as well as rudimentary descriptions of the territory and practices of resident tribes, give tantalizing hints as to the location of that bay. Nevertheless, the location has not been determined, although jockeying among contenders has been fierce and is ongoing. Some researchers have weighed linguistic and anthropological evidence, which they interpret to suggest that Drake's landing place was on the central Oregon coast. ${ }^{20}$ In 2012, the National Park Service named Drakes Bay (Drake's Estero), in Point Reyes National Seashore just north of San Francisco Bay, as a National Historic Landmark. Although evidence is not conclusive, the Park Service found it "most likely" that this was the landing and careening spot Drake chose in 1579. ${ }^{21}$

M. Wayne Jensen, Jr., Director of Tillamook County Pioneer Museum, 1976-2003, theorized that Drake and his crew had instead landed in Nehalem Bay and undertaken several surveys on Neahkahnie Mountain. ${ }^{22}$ When he became museum director, he began to explore this hypothesis. Jensen systematically searched Neahkahnie Mountain, using a sixteenth-century lineof-sight method, and discovered other marked stones and slabs as well as the original resting place of the W-rock. ${ }^{23}$ In 1976, an Oregon State University (OSU) Master's candidate in Civil Engineering, Phillip Costaggini, performed a ground survey to determine the relations of rock mounds and carved stones on Neahkahnie Mountain. He concluded that the data showed similarities to a sixteenth-century survey and that "the artifacts are remains of ancient sur- 


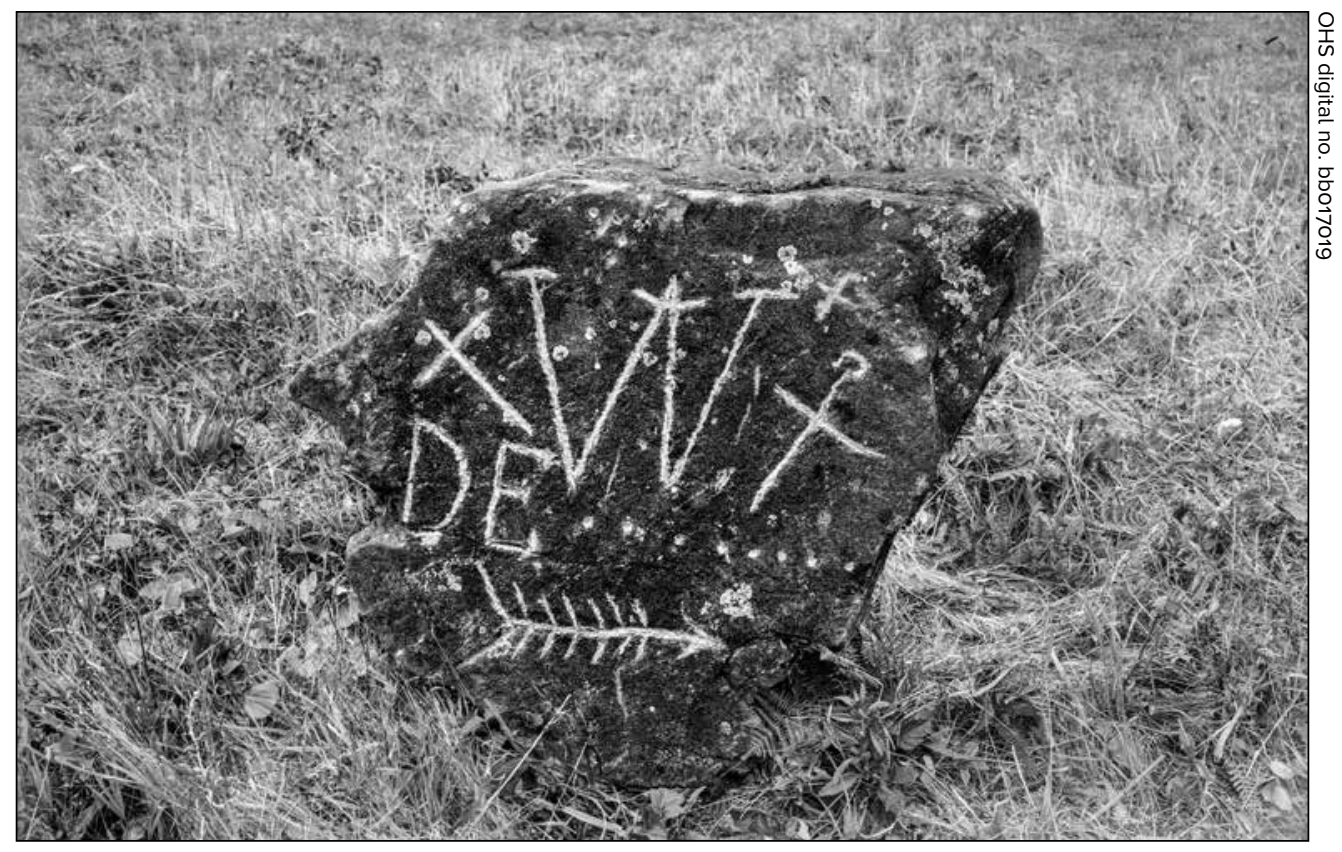

THIS MARKED STONE is one of several found by early Euro-American settlers in the Neahkahnie area. The stones' purpose and messages remain unknown, although there are many theories.

veys, or are acts of possession (or both), performed most probably by early explorers, of whom the English and Francis Drake are leading candidates for responsibility. The usefulness of the conclusions is that the data explain the artifacts better than other, locally published theories." ${ }^{24}$

In 2008, two OSU Master's degree candidates in Engineering Surveys, Peter Seaders and Beth Peutz, re-assessed the Costaggini survey. They determined that it had been executed accurately but that many of the original stones had been moved as curiosities, to protect them as archaeological finds, or for other reasons. The authors stated that, using accurate survey methods now available, they were able to find the stone locations they searched for. ${ }^{25}$ They decided, however, that the purpose of the original Neahkahnie survey was unknown, while also noting that Constaggini had concluded that the stones could not have been used to map treasure. ${ }^{26}$

Other hypotheses - such as the stones having Spanish connections, being associated with early Euro-American historical survey and settlement, or even created by treasure seekers of the fur trade era - remain unexplored. 


\section{TREASURE HUNTING, SHIPWRECKS, AND THE LAW}

Oregon legislation that regulated treasure-hunters in the Neahkahnie area was influenced by federal activity related to protection of archeological sites and by maritime law related to shipwrecks. The American Antiquities Act of 1906 was the first general law in the United States to protect historic sites and structures, including those dating to before colonization by Europeans. Among other things, it required archaeological permits for research on federal lands. The first use of the act in Oregon arose during construction of the Bonneville Dam in the 1930s. ${ }^{27}$ At that time, Oregon had no archaeological permitting process, nor a location to house artifacts. In 1935, the Oregon legislature passed a bill providing for the establishment of a museum, to be located at the University of Oregon, which would house artifacts from sites on public lands. The law also included provisions that became known as Oregon's Historic Sites Act. This act required anyone seeking to excavate at known archaeological sites on public lands to obtain an archaeological permit. An applicant had to be affiliated with a "recognized repository" - such as the University of Oregon's Oregon State Museum of Anthropology - and applicants therefore applied to the president of the university. ${ }^{28}$

In 1966, the federal National Historic Preservation Act took effect, establishing a State Historic Preservation Office (SHPO) in each state and requiring review of potential effects from federally funded projects on state historic properties. This law did not affect Oregon's cultural resources statutes until 1967, when the legislature began to grapple with creating a statutory framework for treasure hunting and protection of shipwrecks and other potential treasure sites. ${ }^{29}$

American maritime law traditionally consisted of two doctrines related to protection of shipwrecks. The "law of salvage" allowed a person to recover property in danger on the sea and return it for a reward. This rule has encouraged destruction and plunder of underwater wrecks, although property owners could limit or prohibit recovery of wrecks. In older maritime cases, salvors won the right to salvage wrecks hundreds of years old by asserting they were still "in peril." In more recent decades, courts have rejected this line of argument. The "law of finds" allowed anyone who found sunken property and took control over it to become the new owner; however, this law applies only to property voluntarily abandoned by the owner. Many statutes, both federal and state, have been passed to protect underwater sites. ${ }^{30}$

Congress passed the milestone Abandoned Shipwreck Act (ASA) in 1987, which gave to a state title to all "abandoned" shipwrecks in the first three miles of the Territorial Sea, if the shipwreck was embedded in the state's submerged lands or eligible for listing in the National Register of Historic Places. This law ended the oversight of federal admiralty law on these shipwrecks. It 
also meant that coastal states had to consider the importance of shipwrecks, decide which ones needed protection, and set up the framework to safeguard them. After several changes to state cultural resource statutes, the Oregon Legislature in 1993 defined an archaeological site as including the seabed, within the state's jurisdiction, that contains archaeological objects and their "contextual associations" - including shipwrecks. ${ }^{31}$

The ASA did not satisfactorily define "abandonment," however, which has led to substantial litigation. Guidance from international law instructs that a coastal state does not necessarily acquire possession or ownership of a sunken vessel located on land or seabed in its jurisdiction merely due to sinking or passage of time. International vessels often remain under the perpetual ownership of their flag country. Pertinently, Spain has never relinquished ownership of ships sailing during the colonial era as part of the Kingdom of Spain. In 2002, Spain notified the United States that salvage or investigation of Spanish sunken vessels requires express consent of an authorized representative of Spain. American courts have supported the United States' recognition of Spanish sovereignty, most notably in 2012 by requiring return of the treasure taken by American Odyssey Marine Exploration from the nineteenth-century Spanish ship Nuestra Señora de las Mercedes. If the probable Spanish sunken galleon is discovered in the sea off Nehalem Spit, this will be an important consideration. ${ }^{32}$

The primary genesis of Oregon's Treasure Trove statute, which lasted from 1967 to its repeal in 1999, was the persistent Neahkahnie Mountain treasure-hunting activity of a Salem housepainter, Edward M. Fire, also known as Tony Mareno. In 1966, when he first sought to dig for treasure on land in Oswald West State Park, there was no state office with formal responsibility to oversee such matters or any permitting system for survey or excavation of a possible "treasure trove." Apparently, Mareno received instruction to apply for an archaeological permit from the University of Oregon, but he received no reply to that application. ${ }^{33}$

Mareno then contacted his state representative, John W. (Jack) Anunsen, and the legislature ultimately passed the Treasure Trove law, allowing treasure-seekers to dig on public land only if they had a permit. ${ }^{34}$ The logic of the statute, and its later amendments, all echo longstanding expectations of what treasure seekers might find at Neahkahnie, based in no small part on related oral traditions. The 1967 statute did not contain a definition of "treasure trove," but the 1973 amendments defined a treasure trove as "money, coin, gold, silver, precious jewels, plate and bullion found hidden in the earth or other private place where the true owner thereof is unknown."35 The Oregon State Highway Department oversaw the permitting process until the Division of State Lands (DSL) took over the responsibility in 1973. 
As part of Oswald West State Park, Neahkahnie Mountain was managed by the Parks Division, then a part of the Department of Transportation. ${ }^{36}$ The initial Treasure Trove statute gave 75 percent of any discovered treasure to the finder and dedicated the remainder to the Common School Fund. The percentage of treasure, or of its value, going to each party later became a contentious issue. ${ }^{37}$

A 1973 amendment to the statute reversed the ratio, with 75 percent of any found treasure going to the Common School Fund. Important to later debates, the 1973 amendment required that if a find had historical value, the object must be placed in a museum and the finder awarded money, from the Common School Fund, equal to the value of the find. Significantly, this provision was the first recognition that treasure troves might have historical value. Also important, the 1973 amendment required permit seekers to provide a geophysical survey pinpointing the treasure-hunting activity in order to limit indiscriminate digging, which had resulted in abandoned holes and trenches along the state's beaches and the slopes of Neahkahnie Mountain. In 1987, the treasure-hunting community convinced the legislature to amend the statute once again, so that the first $\$ 5,000$ of treasure as well as half or less of the remaining value accrued to the finder. All subsequent finds or value would vest in the Common School Fund. Citizens had complained that sending three quarters of the treasure's value to the state disproportionately disadvantaged seekers. ${ }^{38}$

As soon as the initial statute passed in 1967, Mareno applied and was awarded the first Treasure Trove permit. Many other treasure hunters followed in his footsteps. In general, the searchers fell into two categories: seekers for the galleon itself, and seekers of gold or other treasure. The treasure hunters based their searches on tales of Spanish galleons or other Spanish activity, often combined with biblical readings, marked stones, weather-worn patterns on non-marked stones, or other indicators.

\section{THE SEARCH FOR THE WRECKED "TREASURE SHIP”}

Proposals for quasi-archaeological excavations of the ship wrecked on Nehalem Spit have a remarkably long history. E.M. Cherry, the British ViceConsul in Astoria in the 1930s, hoped to salvage the portion of the wreck occasionally visible on the beach. The project would have required building a cofferdam and dredging thousands of yards of sand, costing at least $\$ 30,000$. Cherry planned to raise the boat, salvage the valuable parts, and use the hull as a concession. An article about the effort described the wreck as the boat "thought by many to have been the one that carried the treasure supposed to have been buried on Neah-kah-nie Mountain." Ultimately, the salvage project proved too expensive, and Cherry abandoned his efforts. ${ }^{39}$ 


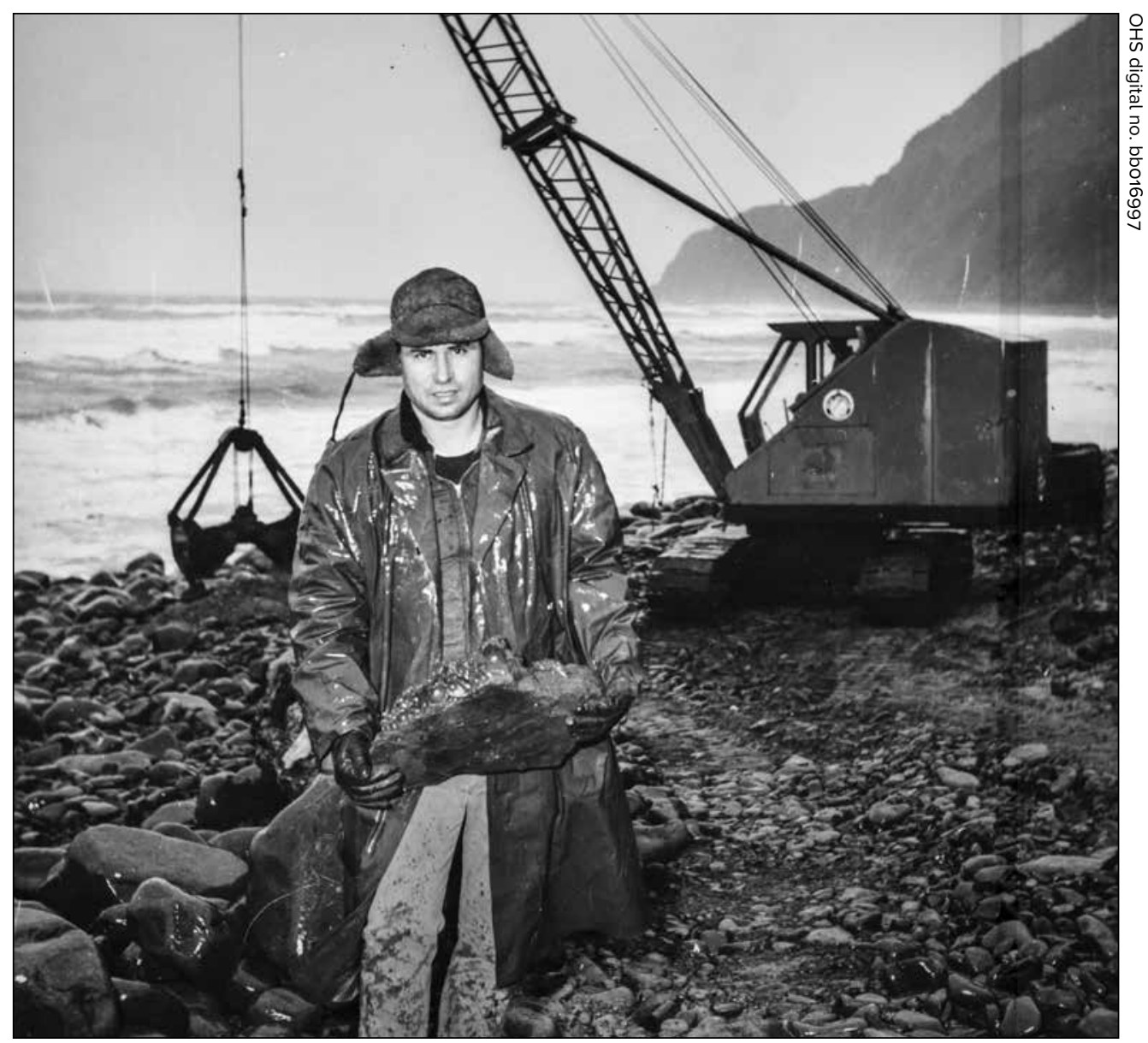

ED FIRE, also known as Tony Mareno, holds a piece of sopastone in this photograph taken on December 29, 1967. He was the first treasure seeker to work under Oregon's new Treasure Trove law. Mareno hunted for treasure vigorously, frequently using bulldozers and other heavy equipment to excavate along the beach, which drew crowds of the curious and also ignited government concern for the beaches and for public safety.

David Clark was the first seeker of the galleon operating under the Treasure Trove statute. In 1979, Clark sought a permit to discover the whereabouts of a Spanish ship he claimed to have discovered via dowsing and that he believed had sunk in 1875 in or just outside Nehalem Bay. DSL cautiously notified him of the need for a permit to search for archaeological items or for treasure on public land and of the many requirements he would have to meet, ranging from archaeological surveys to specifying his treasure- 
hunting methods. ${ }^{40}$ The agency recommended approval only of an exploration permit, "to make certain a ship has been found. Any further plans for search and recovery of any treasure (or artifacts) should be the subject of a separate permit, to be reviewed at that time." ${ }^{41}$ In 1986, James McCanna sought a permit to search for a ship he believed to be a seventeenth century shipwreck. ${ }^{42}$ In 1989, a duo of seekers, Delmar Wagner and Forrest Rigger, focused unsuccessfully on an offshore search for the actual ship. ${ }^{43}$

In the late 1980s, with much publicity from newspapers in Tillamook and the Willamette Valley, the public closely followed the exploits of William (Bill) Warren, owner of Golden Quest, Inc., of Carlsbad, California, as he sought to acquire permission to carry out excavations in the Nehalem area. ${ }^{44}$ Although Warren obtained a DSL treasure trove exploration permit to search for the ship in the waters off Nehalem Bay, the permit did not cover searches in the bay itself or allow removal of objects from the ship. The Oregon State Historic Preservation Office (SHPO) refused to grant an archaeological permit to Warren, stating that a shipwreck and objects associated with it, such as porcelain and china, were archaeological items belonging to the state, and further noting that the Warren plan did not include any archaeologists with expertise in the underwater archaeology appropriate for shipwreck research. ${ }^{45}$ Warren's research design called for remote-sensing surveys of the site, followed by excavation and site-mapping using varied techniques. The plan discussed artifact conservation and handling, with production of an archaeological monograph, and articles "submitted for publication to professional archaeological journals" - but also noted that this was a proposed commercial venture, albeit with archaeological oversight. ${ }^{46}$

Warren's dealings with local residents in Tillamook County and with state officials were prickly. He asked the Vandecoeverings, the owners of Trollers Charters in Garibaldi, who became the largest stockholders in Golden Quest aside from Warren, and with whom he had been discussing chartering boats and equipment, to turn their charter business over to Golden Quest. They refused. ${ }^{47}$ In 1990, the Vandecoeverings applied for their own treasure trove permit to search for the galleon, under the name Garibaldi Treasure Troves. By that time, however, the state had instituted a moratorium on treasure trove permits, and the request did not move forward. ${ }^{48}$

Warren frequently and repeatedly called state officials at DSL and the governor's office, seeking to prime the process for obtaining archaeological and treasure trove permits. This became burdensome to officials, and early in 1989 the DSL director wrote to Warren, stating: "If your insults and threats persist, I shall be forced to take the unprecedented action of instructing our staff to direct your calls through our Capitol Security offices." 49 These measures elicited an intemperate letter from Warren to the Governor's Assistant, 
admonishing officials about their failure to finalize his contract and accusing them of living "in a fairyland-police state." ${ }^{\circ}$ Discrepancies between the state's Treasure Trove and archaeological statutes became a legal tangle as Warren escalated his efforts, and state agencies openly acknowledged and highlighted these conflicts. ${ }^{51}$

LaVerne Johnson's efforts to excavate the presumed Spanish wreck showcase the many problems that even the 1989 moratorium did not solve. Johnson initially wrote DSL in 1998, requesting a permit to explore for treasure in the territorial sea. DSL began negotiations with him on a contract for archaeological investigation of the wreck. Johnson would locate the shipwreck and recover all artifacts, receiving a percentage of their value. The state could have an archaeologist aboard during all exploration and recovery work and would have first choice of items for museum purposes. But Johnson balked at providing even circumstantial information about the ship location without having a signed contract. ${ }^{22}$

Negotiations continued into 1999. SHPO questioned DSL regarding many problems involved in the project: "Salvage of archaeological resources for profit is an ethical issue subject to debate. There is nothing in the draft that specifies what Mr. Johnson is looking for and where he will look. The draft is open-ended, pretty much allowing Johnson to look for anything anywhere. Is that intended?"53 DSL and Johnson continued negotiations into 2000 , now under the state's archaeological statutes, as Treasure Trove laws were repealed in 1999. Finally, the Department of Justice (DOJ) told Johnson that DSL and the Oregon Parks and Recreation Department (ORPD) - removed from the Department of Transportation and created as an independent agency in 1989, and also the home of the Oregon SHPO - did not have the authority to enter into this kind of agreement, citing constitutional problems prohibiting agreements yoking the state to an open-ended obligation to pay and archaeological requirements that necessitated the state's knowing in advance both the wreck location and operational details. ${ }^{54}$ Combined with increasing concern for underwater archaeological sites, searches for the Spanish shipwreck of Nehalem Spit were largely curtailed due to lack of funding and archaeological expertise that would be required to continue such a search until the current archaeological Beeswax Wreck Project.

\section{THE SEARCH FOR GOLD, JEWELS, AND OTHER TREASURE TROVE}

Most seekers came to Neahkahnie not to seek the wrecked ship itself but to search for the treasure they believed was buried on the mountain's slopes. Many varied theories guided their explorations, usually including some aspect of Spanish lore as the touchstone. Milo Merrill, for example, was familiar with Patrick Smith's stories and years of dogged treasure-hunting, and he also 


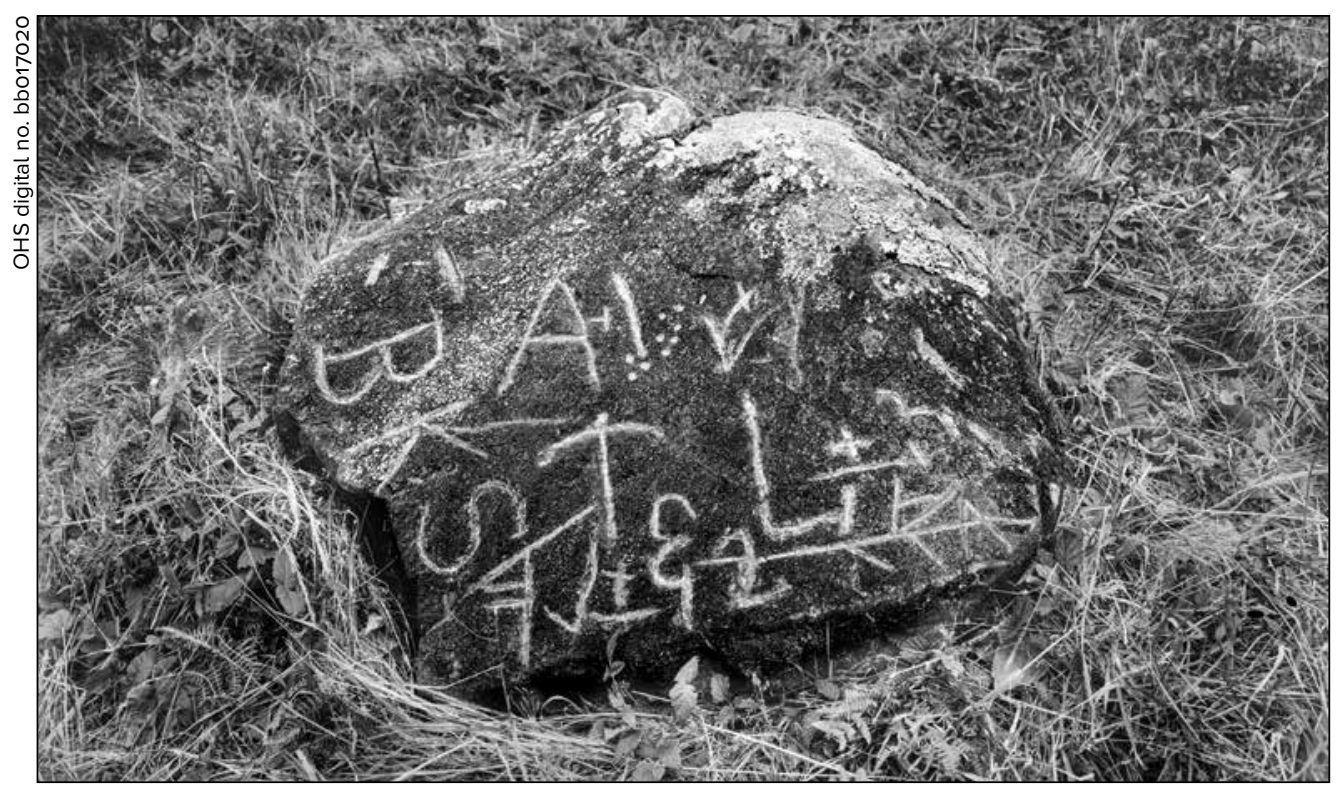

THIS PHOTO shows another one of the enigmatic marked stones found in the Neahkahnie area. This has sometimes been referred to as the "BKS rock" by local historians and writers seeking to make sense of these letters and symbols.

searched the mountain through the 1930 s and 1940s. Merrill believed the Spanish had hidden three hundred caches of treasure in the New World in locations where they planned to start colonies. He claimed to know the general survey locations of twenty such caches on Neahkahnie Mountain, which would allow him to easily locate another twenty. Merrill said he admired the Spanish engineers for their cunning and ingenuity in disguising the directions to the treasure caches and reported that he had learned enough of the code (explained to him by a man friendly with the son of a Spanish engineer who had visited Neahkahnie during Smith's era) to begin from a Spanish survey map. Merrill also claimed he knew what the marked stones meant. ${ }^{55}$

Perhaps the most unusual description of Spanish treasure came from Chris Mehlig of Cannon Beach. He claimed that, in 1961, he and others watched a salvage operation in the ocean that took place over four days and nights by divers from a white Phoenix-type craft and that the craft rendezvoused with a World War II submarine about three miles offshore. Mehlig stated that a treasure trove income tax form was filed, with the taxes on gold worth $\$ 1.25$ million (about 2,900 pounds of gold at the thencurrent price per pound), paid in cash by three men to the Seattle office of the Internal Revenue Service. He conceded he could never discover 
the names of the men, postulating they avoided state permits and illegally kept the gold. ${ }^{56}$

Mareno, who initially hunted for the Neahkahnie treasure from 1967 until at least May 1968, when the State Land Board (a citizen commission that oversaw the Division of State Lands) canceled his permit, drew inspiration both from histories of the Spanish galleon trade and from broad interpretations of biblical sources. He claimed that the key to finding the Neahkahnie treasure lay in decoding the interpretations of eighteenth-century adventurers who sacked the churches of Spain, and he interpreted biblical verses in which the Lord instructed Moses to hew two tablets of stone and place them in the Ark (Deuteronomy Ch. 10, verses 1-3) and which describe the building of Solomon's temple and the crafting of its gold candlesticks and other artifacts (1 Kings 7: 1-51). Mareno was certain he had decoded the Spanish adventurers' interpretations of the biblical verses and their messages on the Neahkahnie stones, which marked where they had buried treasure worth up to $\$ 20$ billion. ${ }^{57}$

Mareno applied for a second permit in August 1988. His beliefs continued to fuse Spanish origin with biblical interpretation and other pointers, as contemporary news reports described: "Fire [Mareno] believes it's no coincidence that a confusing matrix of constellations, Bible verses, underground tunnels and other features appear to mesh with the mysterious glyphic markings on three rocks found on the beach at Neahkahnie over the last 90 years." ${ }^{58}$ The treasure trove permit form required an applicant to enter a specific description and estimated value of treasure trove. In his 1988 application to seek this biblically referenced treasure, Mareno identified "Gold, silver, precious ores, jewels. Unknown value, could be upwards into millions." 59 At that point, Mareno thought the trove he was searching for was worth perhaps $\$ 500$ million. ${ }^{60}$

The likely Spanish origins of the occasionally sighted wreck colored seekers' understanding of what treasure or other artifacts might be available or where they were buried. In 1970, for example, Parks Division staff reported that seekers Don Viles and Wayne Jensen had proposed that Neahkahnie's marked stones constituted a boundary survey of a Spanish colony founded in about 1600 as a rest stop for Manila galleons after the arduous Pacific crossing. Jensen and Viles did not believe, however, that treasure was involved, as colonists' furnishing of food and needed goods to the galleon crews would require little cash. ${ }^{61}$

Most other seekers did believe Neahkahnie held hidden treasure. Orval Keller, who sought the Neahkahnie treasure for about twenty years, believed the rocks were placed on the mountain by the Spanish conquistador Hernan Cortés, carved using the now-lost art of marking stones with shapes, especially animal shapes such as a dog, duck, or rabbit, with each having a symbolic meaning. A duck symbol, for example, meant water, and a rabbit meant gold. ${ }^{62}$ In 1971, he wrote to DSL: "By study of two years I have discovered a lost art on the rocks 


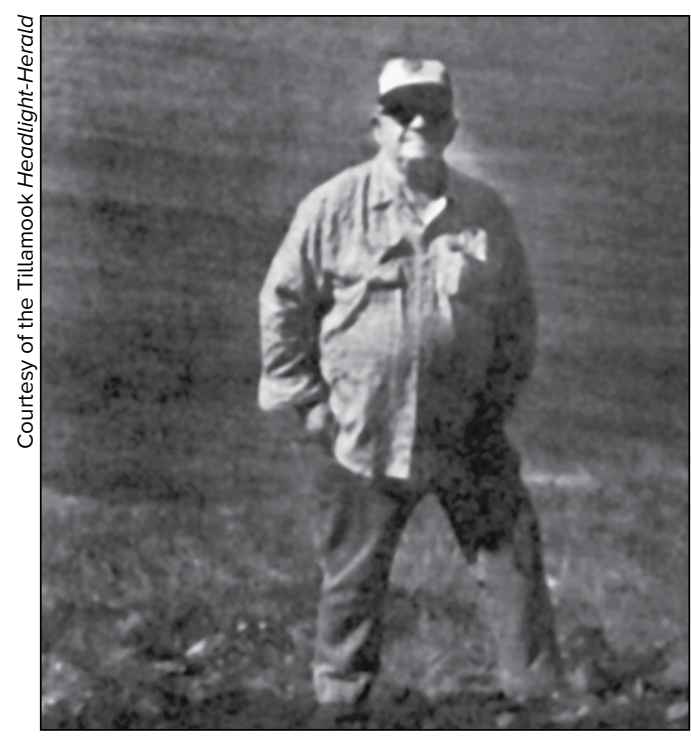

BUD KRETSINGER, pictured here at a dig site in 1983, sought the legendary treasure in the Neahkahnie area for more than twenty years. His theories were colorful and attracted much press, but government officials found the digging on Neahkahnie Mountain to be troublesome, because that land is part of Oswald West State Park. that mark the treasure on Mt. NeahKah-Nie... These rocks are worth some thousands of dollars. They are a treasure within themselves. There is treasure on that $\mathrm{Mt}$. and I know where it is.... These rock [sic] are chipped and shaped and you have to set them in proper light to see what was put on them because this is secret carvings." 63 The division declined to issue Keller a permit or extend any existing permit, citing removal of the marked stones from state property. ${ }^{64}$ In an internal letter a year later, however, the division recommended that Keller be invited to appear before the Parks Advisory Committee to try and convince them he had a theory worthy of serious consideration. If successful, he would then have to convince the State Highway Commission for a permit to dig. ${ }^{65}$ Keller and his son Dick were offered a permit in 1973, but they abandoned Neahkahnie treasurehunting attempts that same year. ${ }^{66}$

Four men, including Dick Keller and Lloyd and Dean Grimes, formed the Tillamook Treasures company in 1970. John Hathaway, the group's attorney, had a 20 percent owner share, as did each of the other four men. Subsequently, a quartet of seekers, including Lloyd Grimes and two others originally involved in Tillamook Treasures, split off and formed an unnamed treasurehunting group in 1973. This group of seekers wanted a six-month permit, with the opportunity to set their own digging schedule and dig in more than one place. Evidently, a man named Contreras with some unspecified connection with the National University of Mexico told Grimes what the symbols on the rocks meant and reported that they were of Spanish origin, marked by a group "working on behalf of a government official in an unofficial capacity." Contreras also sent literature that was used by the treasure-hunters to locate places on the mountain. ${ }^{67}$

In 1974, Tillamook Treasures applied to DSL for a treasure seekers' permit. As evidence for the validity of their search locations, Tillamook Treasures cited the meanings of the marked rocks. DSL sought the opinion of the University of 
Oregon's Museum of Natural History, whose director was at pains to describe what museum staff defined as "authentic" with respect to stone markings: "We mean by the term, authentic, that there be substantial evidence that the markings are meaningful symbols put there by Europeans who landed on the Pacific Northwest coast before approximately the beginning of the nineteenth century." He cautiously added that, by itself, such evidence would not necessarily indicate treasure. ${ }^{68}$ Museum personnel visited Tillamook to examine sixteen of the treasure-hunters' rocks at Lloyd Grimes's home. The stones common varieties of rock found locally, primarily weathered basalt - were clearly marked by humans with various figures; the applicants explained they had scratched over the markings to make them clearer. Museum personnel concluded: "we have seen no evidence that these objects are of any considerable antiquity measured in centuries, or that they represent any recognized artistic tradition, any identifiable culture, or any demonstrable historical event. In our opinion, they are not artifacts in the generally accepted sense."69

Nevertheless, in 1979, Grimes, relying on the same purported hieroglyphics on the rocks, sought to convince DSL that his methodology of finding the Neahkahnie treasure was valid and thus merited a permit. ${ }^{70} \mathrm{He}$ met with DSL officials, who requested seismic tests and electrical resistivity in areas where Grimes thought a tunnel was located..$^{71}$ The state was trying to determine whether Neahkahnie should be subjected to more digging. DSL was open to other suggestions as to how best Grimes might verify his claims of the treasure's location, as long as they did not shift a cost burden to the state. ${ }^{72}$ SHPO hovered nearby, willing to have an archaeologist review a research proposal but stressing the importance and fragility of archaeological sites. ${ }^{73}$

Grimes sought to spell out his methodology to DSL and justify the need for additional searches. ${ }^{74} \mathrm{He}$ also explained publicly that he had photos, test reports, and aerial photos that showed the twelve rocks whose designs coincided with statements in the Bible: "We have used a great deal of modern technology; we've had to use this to prove what the Bible and the rocks already say. All that's used is what we can read from the rocks, that coincides with the Bible.... The twelve stones came from the Wailing Wall. They were placed on Neahkahnie to mark the hiding place of an immense biblical treasure. The Bible says its there, my camera says it's there."75 His partner Bud Kretsinger was a longtime treasure hunter who, by 1983, had worked on the Neahkahnie treasure for twenty-two years. He clarified that although there were several treasures buried on the mountain, "The one we want has biblical connotations. Part of it is treasure of King Solomon and the Queen of Sheba, and ancient scrolls written by Moses himself. We think this is the main one. If we get to this one, it'll tell us all the secrets of 
the others." ${ }^{76}$ Both men complained about the permitting process when the state, having granted three test permits, shut down the dig after the second attempt and the state-required archaeologist left. ${ }^{77}$

Other treasure trove permit applicants made specific reference to Manila galleons and purported Native oral tradition. A.W. Johnstun's 1975 permit request specified three locations where he believed treasure was located: "The one at the Barview area [near Neahkahnie] I think may be the San Francisco Xavier ship. It has beeswax and a little silver. This is the ship that was alleged that those who were on board hid the treasure on land nearby and I would like permission to go after that hidden treasure which I think is located within a mile of the ship."78 In 1981, John Bergeson implicated the Native peoples of the area in concealing the Neahkahnie treasure trove from Spanish shipwrecks:

The Indians have also given early settlers several different versions of the Neahkahnie treasure trove. This was done I believe, to deliverately [sic] confuse them with the object of concealing its true location.... It is my contention that local Indians over the course of centuries, systematically looted various shipwrecked vessels of anything valuable or useful; that they cached variouse [sic] objects of value whether it be gold and silver bullion or coins as well as other jewels and vessels of gold and silver in one or more locations, the contents of which were to be used only in times of absolute need.... It is my purpose to seek out the possible location or locations of these caches. ${ }^{79}$

There is nothing in the archaeological record, nor the oral tradition of NehalemTillamook people, to support this claim. Nonetheless, Bergeson specifically requested a map from the state government showing locations of "Indian villages" so that they might be excavated for hidden treasure. SHPO Archaeologist Leland Gilsen wrote to DSL in response, identifying the request as an immediate threat to village sites on state lands in the Neahkahnie Mountain area and stating that SHPO would "not supply him with maps showing the locations of Indian villages nor would we cooperate with amateur treasure hunters excavation or digging in Indian village sites anywhere on state lands."80

In 1982, Lloyd Grimes and Ken Hughes proposed to dig for treasure on Neahkahnie, also using the purported galleon shipwreck as the underlying reason for the search: "The most likely source of any possible 'treasure' on Neahkahnie Mountain appears to be that of an unfortunate Spanish ship blown off course and wrecked on the Oregon coast.... The proposal calls for up to three test trenches 5 feet wide by no more than 20 feet long and 10 feet deep. Excavation will be by hand using shovels and trowels to clear away overburden, and shovels and trowels to excavate any archaeological remains encountered." ${ }^{11}$ Working as a plumber in Garibaldi, Hughes had heard talk of the Neahkahnie treasure. He based his treasure theories primar- 
ily on the W-rock and other rocks in the Neahkahnie area, his choice of site resulting from new interpretations of the marked stones. ${ }^{82}$

Although a treasure hunter, Hughes in his application bowed to state requirements for archaeological protection of potentially historic sites, pledging that preservation and curation of artifacts would follow archaeological standards. Hughes and Grimes also promised an archaeological report on the excavation, which would be presented to SHPO on completion of curation. ${ }^{83}$

One applicant to DSL claimed to be searching for, or possibly to have found, the Ark of the Covenant. In 1983, DSL asked the Justice Department whether that item would

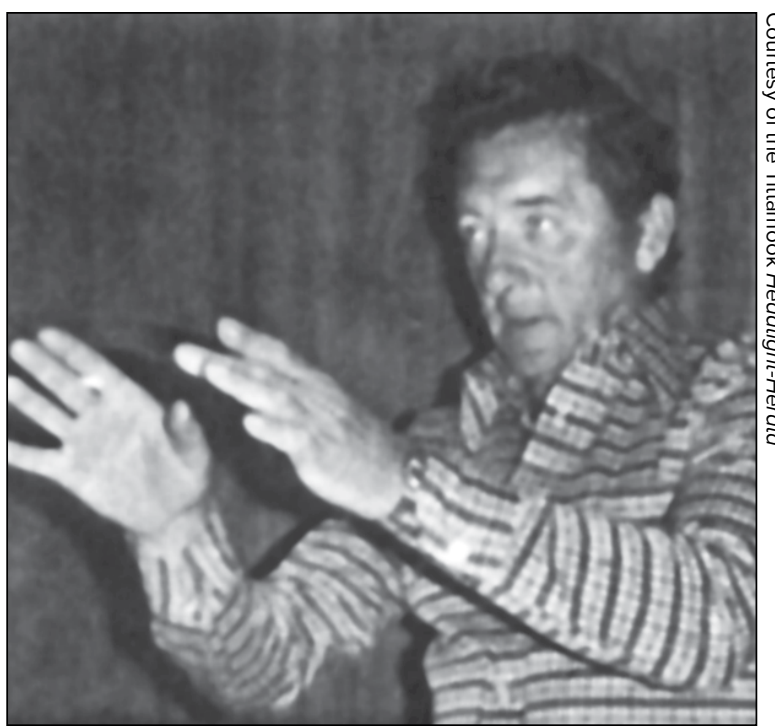

DEAN GRIMES searched for the Neahkahnie treasure with different groups, including Tillamook Treasures, and in partnership with Bud Kretsinger throughout the 1970 s and beyond. His theories, fascinating and detailed, attracted publicity, but his searches fueled government concerns for the integrity of Oswald West State Park. Grimes is pictured here in 1983 , explaining to a group the problems he and Kretsinger experienced during their treasure-hunting efforts.

be considered Treasure Trove

or would fall under archeol-

ogy permits. The Attorney General's office investigated the question in all seriousness. They determined that, if it were lined with gold, the Ark would be considered treasure trove under state law and that, whether or not it was gold-lined, it would also be an archaeological object. The Attorney General noted that both the state's archaeological statutes and the treasure-trove laws would apply. The two statutory schemes laid conflicting claim to the same objects in many instances, and their respective requirements did not necessarily protect important historical resources. Importantly, the Justice Department also concluded that "an individual not associated with an institution may be issued a permit to remove archaeological material or treasure-trove." 84

John Davis's effort provides a good example of the mixture of purported clues, marked rock interpretations, and modern technology used by some seekers. His attempts to gain permits also serve as an exemplar of state law in the late 1980 s that allowed individuals not affiliated with institutions to apply for archaeological and treasure trove permits. Davis (who styled himself "A 
Treasure Hunter"), in the name of his company, Corpus Land Investment, filed five treasure trove applications in 1989, under the mistaken impression that most of his target area was state land in the Neahkahnie and Nehalem Bay area, including a small island in the bay. DSL informed him that only one of his applications actually included state-owned land, and that he might also have to obtain an archaeological permit for activities that would disturb the surface of any public land. ${ }^{85}$

Davis used aerial photos and "rocks with markings" that he determined through close analysis to be both location monuments and clues to the shipwreck. Davis concluded, based on the letters "DE" on one marked stone, that the shipwreck was Spanish and occurred in 1632. He scanned the selected area of Nehalem Bay with underwater probes and described finds of "buried Nodules on the inland beach" at very low tides. He anticipated using a small barge, dredge, and perhaps a two-person submarine to displace sand and dig for artifacts and treasure, which he believed "could be gold and other values." Davis's one valid application did not move ahead, however, because state agencies were beginning to focus seriously on the conflicts between the Treasure Trove statute and archaeological protection, and DSL was requesting a treasure trove moratorium. ${ }^{86}$

After the moratorium went into effect, treasure-seekers occasionally continued activity in the Neahkahnie area without permits. ${ }^{87}$ Even now, nearly two decades since the 1999 repeal of the law, the interest in searching for the purported Spanish treasure is alive and well. SHPO continues to receive occasional calls from people interested in hunting for the Neahkahnie hoard. Sometimes, they are willing to tell state officials where the treasure is - if the state agrees to split the gold, silver, and jewels with the finder who claims to know the location. ${ }^{88}$

\section{THE PERILS OF TREASURE-HUNTING TO PEOPLE AND LANDSCAPE}

Neahkahnie Mountain can be a dangerous place. Its western slope is a steepfaced cliff that plunges straight to the sea, and its flanks are likewise steep. Treasure-hunters commonly neglected even basic safety or environmental precautions, as no statute required them. The permit system established under the Treasure Trove statute also did little to mitigate the harm done to Oswald West State Park's beaches or to the mountain itself. State officials during the 1980 s and 1990s were acutely aware of Neahkahnie's welldeserved nickname, "the mountain of a thousand holes," resulting from the treasure-digging that had taken place there for decades. ${ }^{89}$

At least three treasure-seekers lost their lives on Neahkahnie Mountain. In 1931, Charles Wood and his son Lynn Wood of Portland excavated a thirty- 
foot hole on the mountain, without supports of any kind. A cave-in killed both men. ${ }^{\circ}$ In 1990, two treasure hunters rappelled down Neahkahnie Mountain and began searching for treasure in an inflatable raft. Waves swept them into a cave, and both men were stranded. One of them, Samuel Logan, was pulled back out to sea by another wave and drowned. ${ }^{91}$

The depredations of early-twentieth-century treasure seekers ranged from those of three Swedes who, in 1905, destroyed an area "as big as a house" with hydraulic hoses to those of enthusiasts digging shafts twenty and thirty feet deep. Samuel Reed, builder and owner of Neahkahnie Tavern, often saw the flanks of Neahkahnie he owned turned into a shambles by treasure seekers, although he granted permission to any who wanted to search for the fabled treasure. In the 1940s, Patrick Smith's erstwhile partner, Charlie Pike, teamed up with two others and brought in a bulldozer, then a diamond drill, sinking a shaft into the mountain that was forty feet deep and four feet wide. ${ }^{92}$ The Nehalem Valley Historical Society described two deep holes dug on private property in the Neahkahnie development originally plotted by Reed; one was 8 feet wide and 80 feet deep, dug by treasure seekers in 1947 and 1948. Another landowner, farther down the mountain, had two holes, about 12 feet apart, both 30 feet deep. ${ }^{93}$ In 1958, treasure-

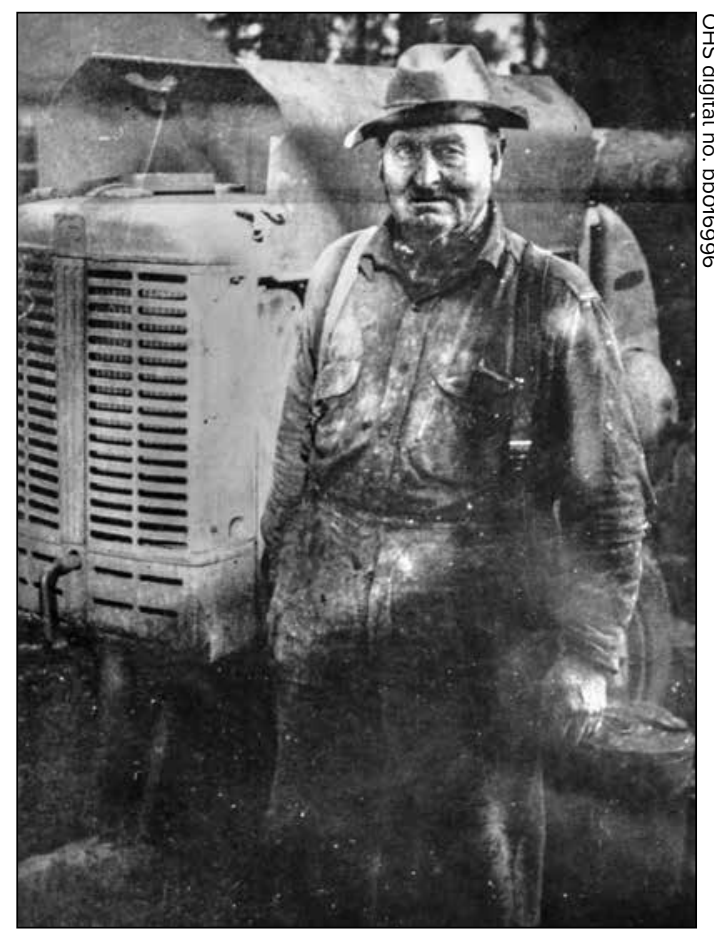

CHARLIE PIKE was a well-known treasure hunter of the late nineteenth century who frequently teamed up with another famous seeker, Patrick Smith, to search for the fabled Neahkahnie treasure hoard. Pike is pictured here in November 1947. seekers from Seattle dug a pit 125 feet deep just a few yards from Highway 101 - probably the deepest ever excavated for the Neahkahnie treasure. They based their activities on a "witching stick" that pulled downward when baited with a gold ring held over the yawning shaft. ${ }^{94}$

Treasure-seeking on the actual beach presented additional conflicts in an area heavily used for public recreation. In 1967, Mareno used a tractor bulldozer 
to plow through the sand of Manzanita beach, and then an augur-type drill to bore deeper. ${ }^{95}$ Concerns about this major excavation on the beach led the State Land Board in March 1968 to take the extraordinary action of imposing a $\$ 10,000$ bond on the Mareno permit. He did not comply, and a month later, the land board voted to grant Mareno his requested permit extension until May, then terminate the permit - although he could reapply after October. ${ }^{96}$

After issuing a permit to Orval Keller in 1971, the Highway Division refused to extend it, or issue new permits, after Keller admitted to removing rocks from Neahkahnie in contravention of archaeological statutes that prohibited excavation or removal of any "materials of archaeological ... nature" without a permit from DSL and the University of Oregon President. Officials were troubled by the extensive excavations on the mountain and its lower slopes as well as the beach areas, pointing out to elected officials that environmentalists and others disapproved of any further exploration. ${ }^{97}$ In 1974, Paul Wolf requested a permit to dig a ten-by-thirty-foot hole on the beach at Manzanita with a backhoe and bulldozer. The State Land Board approved the permit. Wolf dug on the beach, discovered no treasure, and fulfilled all permit conditions, refilling the hole. In a private communication, however, DSL described reservations, noting that usage of Manzanita Beach was considerably higher on weekends and expressing desire to avoid future potential conflicts between treasure hunters and the public using the beach. ${ }^{98}$

After such experiences, the agencies became quite guarded. In response to a prospective seeker a few years later, the DSL director explained, "I simply can't obtain approval of a carte blanche permit. Too many people before you have not shown common sense, and the State's (public's) land is abused. You have the same rights as any other member of the public to visit our lands. Exploration as used in our Treasure Trove statute implies a conscious, organized program designed to achieve the goal, a discovery of treasure trove." 99

Both DSL and Parks had continuing problems of compliance and environmental damage, most especially from the Grimes and Kretsinger group in 1983. Parks decided to revoke the group's permit after repeated infractions and a lack of cooperation. The archaeologist hired by the team - before she quit due to non-payment - reported safety concerns, stating that the treasure-seekers' hole was ten feet deep with vertical sides and no side support. State officials discovered it ultimately was excavated to eighteen feet. The archaeologist also noted that "the younger fellows who were doing the digging were becoming more and more aggressive and hostile as time progressed without finding a treasure."

Three months later, the treasure seekers illegally brought in a backhoe to dig a hole at Elk Flats that was fourteen feet deep when Parks officials discovered it. Kretsinger could only produce an expired permit. Officials 
made the backhoe operator refill the hole. It cost $\$ 483$ just to repair the damage to the meadow and trail, but the park foreman noted damages to aesthetics and the environment exceeded this dollar amount: "The destruction of over 800 square feet of this natural meadow significantly distracts from its former beauty, and no amount of money or skill can fully restore it now. Only time will tell to what extent it may recover."101 DSL cancelled the treasure hunters' permit, and the Parks Division notified them that it was keeping the entire bond amount of $\$ 500$ to help cover restoration costs. ${ }^{102}$

Parks had similar qualms concerning threats to natural and visual resources resulting from Mareno's vigorous searches in the Neahkahnie area and also worried about dangers to the public on and near these popular state park lands, noting in one internal 1988 memorandum: "Dangerous situation because of caverns/tunnels." ${ }^{103}$ Mareno and the state went back and forth on permit provisions in 1988; finally, the Parks Division granted the permit but later cancelled it on grounds that Mareno had dug a trench deeper than allowed. Mareno concurrently abandoned the permit because it was too limiting. ${ }^{104}$ In 1989, when Mareno applied for yet another permit (TT-12), the Parks Division decided an additional ocean shore permit would be required, because the amount and size of Mareno's equipment would both obstruct public access to the beach and greatly alter the ocean shore. ${ }^{105}$

Finally, in 1989, Parks and DSL decided to implement a moratorium on new permits. The goal was mainly to protect archaeological sites, but officials also cited environmental concerns. Years of treasure hunters had left the mountain crisscrossed with trenches, tunnels, and pits. "I wish they'd find that thing," State Parks Director Dave Talbot said, "they are about ready to tear that mountain down." 106

In recent years, OPRD has occasionally identified and filled some of the mountainside holes as part of the operation of Oswald West State Park, but others remain. In such thickly vegetated areas, they are well concealed and quite hazardous. Tourists' dogs have been rescued from these pits, and elk have been found dead in them. Documentation of the holes on public land is hampered in part by lack of knowledge of their precise location, and also by the desire not to unintentionally encourage a new generation of treasure seekers, since no treasure hunting is now allowed on state-owned lands. ${ }^{107}$

\section{TREASURE TROVE QUALMS: MORATORIUM, FAILED SOLUTIONS, AND REPEAL}

State officials recognized early on that the Treasure Trove statute had many problems. In 1973, DSL staff expressed frustration about the law's language, allowing collection of artifacts on state lands for "non-commercial purposes." The only way DSL could determine whether the purpose was commercial 
was to inquire into the collector's intent - a difficult if not impossible task. ${ }^{108}$ Increasingly cautious about the potential damage to state resources, DSL by the early 1980 s began issuing treasure trove permits only for non-intrusive geophysical exploration. As of 1986, the state required a performance bond from seekers to ensure they would be responsible for any cleanup costs. After 1989, DSL required applicants for shipwreck exploration to work with a professional archaeologist and apply for archaeological permits. ${ }^{109}$

The turning point in the widening perception that the Treasure Trove statute was more problematic than valuable came in 1987. That year, treasure-hunters persuaded the legislature to grant finders 100 percent of the first $\$ 5,000$ found, and up to half the remaining value, with the rest going to the Common School Fund. ${ }^{110}$ Although the idea was to widen citizen opportunity to benefit from found treasure, there were only two more applications in 1987 and one (from Mareno) in 1988. ${ }^{11}$ DSL also realized in 1988 that the Treasure Trove statute had been amended several times, but the administrative rules issued in 1967 were never amended, undermining implementation of the revised law. ${ }^{112}$

The State Land Board issued a treasure-hunting moratorium in late 1989 until new rulemaking could be completed. The Oregon Parks and Recreation Department (OPRD) prepared to do likewise. Parks also proposed legislation classifying shipwrecks as archaeological sites under Oregon law to prevent looting. In a letter to a treasure hunter's attorney, the OPRD director stated explicitly: "My purpose in this proposed legislative effort was to protect shipwrecks and other archaeological sites from exploration by private interests whose primary objective was profit from artifacts discovered on public lands. I feel such resources belong to the people."113 At that time, to be listed as protected sites under state law, shipwrecks had to be specifically connected to Native peoples and culture. Thus, the Beeswax Ship would have been unlikely to qualify for protection, despite its indirect connections to Nehalem-Tillamook history.

Treasure seekers interpreted these state actions as repudiating their rights to follow the earlier American maritime laws of salvage and finds, although they had already lost this battle at the federal level with the passage of the Abandoned Shipwreck Act. Dennis Messoline, an attorney representing Tony Mareno, accused Parks Superintendent Dave Talbot of empire-building and said Parks wanted to keep all treasure for itself. Bill Warren resigned (or was fired by the stockholders) as president and chairman of Golden Quest, Inc., the company he had created to search for the Spanish treasure ship. ${ }^{114}$ Publicity during the initial 1989-1991 moratorium period triggered a renewed interest in Neahkahnie Mountain, and the state received another thirteen applications, many of them from well-known treasure hunters such as Mareno, Warren, and LaVerne Johnson. ${ }^{115}$ In 1991, the State Land Board extended the moratorium 
indefinitely, citing the direct conflict between the Treasure Trove Act and state archaeological statutes as well as the legislature's failure to decide the matter thus far. ${ }^{116}$

After the moratorium was in place, the state grappled with the legal conflicts. A 1992 informal committee identified several issues. These included delineating what constituted treasure trove versus archaeological resources; the problem of historical objects needing protection whether they were considered treasure trove or not; the failure of the laws to penalize casual removal of archaeological resources in treasure trove and other situations; and the need for a "pre-inventory" of treasure sites with archaeologists and potentially affected Indian Tribes. ${ }^{117}$

After much work, by 1998, the agencies still could find no way out of the maze. Said exasperated DSL staff, "Treasure trove makes no sense, except that it's difficult to carry on a secret search on public lands. Aside from that, if you knew where money or goods worth thousands or millions was stashed on public land, would you call us and get a permit if you also knew that when you found it you'd get at best a partial share, and if it was goods you'd have to turn it over to us?"118 At the governor's direction, DSL tried to resolve the conflicts by convening a Treasure Trove Work Group, with members from SHPO, DSL, the Commission on Indian Services, and the treasure-hunting community seeking to develop acceptable revisions. The parties could not reach agreement. ${ }^{119}$

In addition to the legal conflicts, permitting requirements had grown over the years. Because the Treasure Trove statute simply required the DSL Director to issue a permit, it failed to take into account areas closed to exploration via local zoning or site planning. OPRD, for example, had adopted a policy in 1989 not to allow any further treasure hunting in state parks or on the beaches. But the Treasure Trove statute gave DSL no discretion to deny a permit, regardless of such agency closures. Nor did the law require DSL to consult with the land-owning agency. DSL also had no specific statutory authority to require bond or insurance of potential treasure-seekers, although DSL did begin to require bonds anyway, beginning in the late 1970s. Very problematically, the law contained no guidance on valuation of found items, apart from the face value of money. Finally, the Treasure Trove statute provided no penalties for violating permit terms, although several instances of violation occurred. DSL could only keep the bond it had required of the seekers to cover restoration costs. ${ }^{120}$

There were also specific problems related to shipwrecks. Efforts by Oregon lawmakers to classify shipwrecks as archaeological sites were galvanized by passage of the Abandoned Shipwreck Act of 1987. This recognition led the state to revisit several pressing issues that affected wreck sites in state waters. Lawmakers realized that the potentially astronomical value of a shipwreck's recovered artifacts - especially in the case of a sunken Spanish galleon - 
coupled with the paying of a required finder's fee, could potentially bankrupt the Common School Fund. ${ }^{121}$ Fueling these concerns was a spectacular find of a Spanish treasure ship off the coast of Florida. The Nuestra Señora de

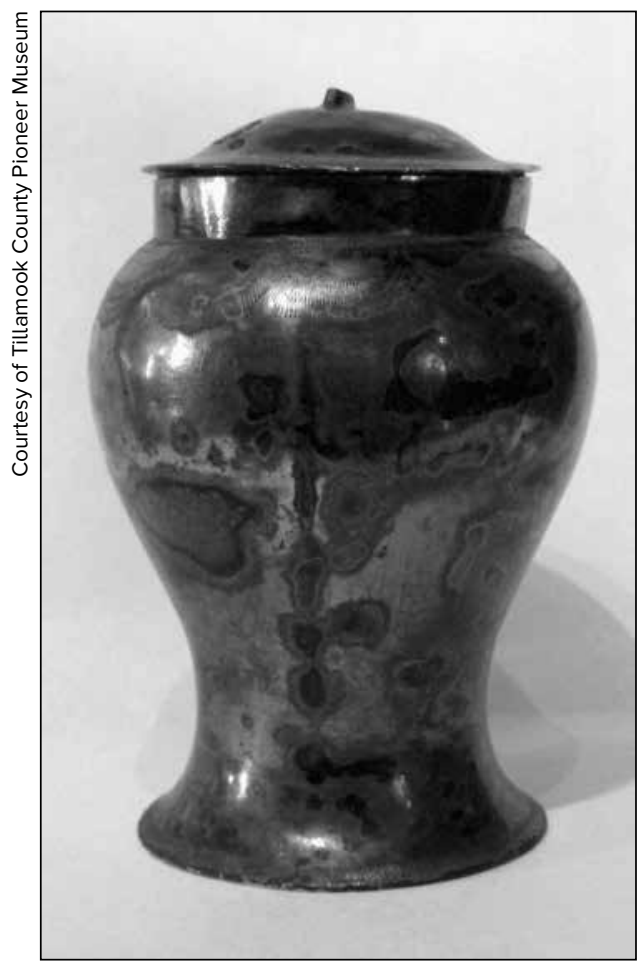

A MR. TUTTLE found this small silver jar near the likely Spanish shipwreck site at low tide in the late nineteenth century. It was probably used by priests for holding holy oil and is part of the Tillamook County Pioneer Museum's permanent collection.

Atocha was the most heavily treasureladen of a seventeenth-century Spanish fleet that sank about thirty-five miles west of Key West in September 1622. The wreck was finally located in 1985 by salvor Mel Fisher after a sixteen-year search. After extensive legal battles, the U.S. Supreme Court awarded the wreck exclusively to Fisher, against the state of Florida's claims to ownership. The wreck is the richest sunken treasure find in U.S. history. The Atocha carried 1,038 ingots of silver (amounting to 24 tons), 180,000 pesos of silver coins, 125 gold bars and discs, 1,200 pounds of worked silverware, and hundreds of pieces of beautiful jewelry, among other items. ${ }^{122}$ If any Oregon shipwreck found by salvors claiming the finder's fee carried even a fraction of this spectacular cargo, the state would land in dire financial straits from making the required payment.

The experience with the Treasure Trove statute showed, among other problems, the gaps in Oregon's cultural resources protection laws relating to shipwrecks. Citing existing protections for Native American archaeological sites, the state in 1989 granted protection to shipwrecks whose crews were known to have interacted with Native peoples, but shipwrecks without such contact remained unprotected. The statute's lack of clarity on Native interactions and the two-tier protection was a major problem. Two Attorney General's opinions, in October 1988 and April 1989, trying to explicate the meaning of "archaeological object" in shipwreck situations, only demonstrated how unclear, conflicting, and unwieldy the statutes were in practice. ${ }^{123}$

Clarification of some issues improved as the legislature amended the ambiguous statutory language. OPRD in 1998 asked the DOJ: Would salvage 
operations of a presumed seventeenth-century Spanish ship in Oregon territorial waters require an archaeological permit, or was the shipwreck not an archaeological site under the law because it was a European ship? DOJ concluded that such a shipwreck would be an "archaeological site," because the law now specifically included shipwrecks in its definitions. Items found at such a site would be considered "archaeological objects" under the statute as amended in 1993. This conclusion finally granted protections to non-Indigenous objects that were part of the physical record. ${ }^{124}$

Amidst these many controversies, Oregon's Tribes also took a renewed interest in the Treasure Trove statute, citing the damaging effect of treasure hunting on archaeological sites of cultural and historical significance and writing in support of repeal. By 1998, the agencies were in an unresolved quandary, and finally, DSL recommended repeal of the Treasure Trove statute. With agency and tribal support, the legislature repealed it in 1999. ${ }^{125}$

Neahkahnie's treasure legend is now a legend only: no more treasurehunting is allowed in any part of Oswald West State Park, including Neahkahnie Mountain and the beaches. Nevertheless, public interest in the treasure of Neahkahnie Mountain remains high, as recurring news and web articles attest. ${ }^{126}$ The potent influence of the probable galleon wreck - most likely the Santo Cristo de Burgos - and the many treasure tales that were fashioned around the unfortunate ship's fate will always fascinate visitors to the north coast. Fevered dreams of treasure prompted generations of seekers to riddle Neahkahnie's landscape with pits and trenches. Now Neahkahnie Mountain, no longer subjected to treasure hunting, is slowly recovering from being The Mountain of a Thousand Holes.

\section{NOTES}

The research on the treasure-hunting traditions in the Neahkahnie Mountain area in this article was made possible by the assistance of the Oregon Parks and Recreation Department staff in Salem, Oregon, and the Oregon State Historic Preservation Office staff. We also thank the Oregon Heritage Commission for supporting oral history research relating to the study area and the Nehalem Valley Historical Society for providing important secondary literature on Nehakhanie Mountain treasure-hunting, both historic news articles and booklets. We especially acknowledge the Tillamook County Pioneer Museum staff for their help in locating and photographing galleon-related artifacts in their collections.

1. Dennis Griffin, “There's Gold on Them Thar Beaches or Searching for Treasure in All the Wrong Places: Oregon's Attempt to Address the Public's Lure of Shipwrecks and Treasure Trove," p. 6, paper delivered at the 62nd Annual Northwest Anthropo- 
logical Conference, Association of Oregon Archaeologists Symposium, Newport, 2009, copy available at the Oregon State Historic Preservation Office, Salem, Oregon, [hereafter Oregon SHPO).

2. Samuel A. Clarke, Pioneer Days of Oregon History, vol. 1 (Cleveland, Ohio: The Arthur H. Clark Company, 1905), 155-76.

3. Elizabeth Derr Jacobs, n.d., Ethnographic Notes: Field Notebooks, Folklore, and Ethnography Based on Three Months' Fieldwork among the Tillamook Salish, Garibaldi, Oregon, unpublished manuscript in the Melville Jacobs Collection, University of Washington Special Collections, Seattle.

4. Mrs. John [Mary] Gerritse "Gerritse family," unpublished interview transcription Seaside History Museum collections, Seaside, n.d.

5. Larry Morris, "Astor Expedition (18101813)," The Oregon Encyclopedia, https:// oregonencyclopedia.org/articles/astor_expedition_1810_1812/\#.WugXTsgh2MK (accessed May 6, 2018).

6. Clarke, Pioneer Days of Oregon History, vol. 1, 160.

7. Ibid.

8. Steven Dow Beckham, "Silas Bryant Smith," Eminent Astorians, Karen Kirtley, ed. (Salem.: East Oregonian Publishing Company, 2010), 195-214.

9. John Hobson, untitled letter to the Oregonian, reprinted in "North Pacific PreHistoric Wrecks. Well Known Pioneers Write Concerning Them," Oregon Native Son, 2:5 (October 1900): 222-23.

10. Ibid.; Hult, Lost Mines and Treasures of the Pacific Northwest (Portland, Ore.: Binfords \& Mort, 1964), 16-17.

11. Ibid.,19.

12. Ibid., 37-38.

13. Ibid, 17.

14. Jane Comerford, At the Foot of the Mountain: An Early History (Portland, Ore: Dragonfly Press, 2004, 2010), 120.

15. Garry David Gitzen, The Treasure Rocks of Neah-kah-nie Mountain (Wheeler, Ore.: Fort Nehalem Publishing, 2012), 15-16, $33,54,76$.

16. Comerford, At the Foot of the Mountain, 120.
17. Samuel J. Cotton, Stories of Nehalem (Chicago, Ill.: M.A. Donohue \& Company, 1915), 57.

18. Thomas Rogers, untitled column in "North Pacific Pre-Historic Wrecks. Well Known Pioneers Write Concerning Them," Oregon Native Son 2:5 (October 1900): 225-26.

19. Gitzen, The Treasure Rocks of Neahkah-nie Mountain, 20. Some of the marked stones were later placed in the Tillamook County Pioneer Museum. Others were held in the private collection of Wayne Jensen, Director of the museum from 1976 to 2003 Comerford, At the Foot of the Mountain 65-79. This source gives a thorough overview of the Reed development at Neahkahnie, including the Neahkahnie Tavern.

20. John Lyon, “Francis Drake's 1579 Voyage: Assessing Linguistic evidence for an Oregon Landing," Anthropological Linguistics 58:1 (2016): 1-51.

21. See National Park Service, "Point Reyes National Seashore California," Discover our Shared Heritage Travel Itinerary: American Latino Heritage, n.d., https://www. nps.gov/nr/travel/american_latino_heritage/ Point_Reyes_National_Seashore.html (accessed June 25, 2017).

22. Gitzen, The Treasure Rocks of Neahkah-nie Mountain, 22-34.

23. Ibid., 21-23.

24. Phillip A. Costaggini and Robert J. Schultz, "Survey of Artifacts at Neahkahnie Mountain, Oregon," Oregon State Civil Engineering Master's Thesis, 1976-81, Reproduced in Garry Gitzen, Francis Drake in Nehalem Bay 1579: Setting the Historical Record Straight (Wheeler, Ore.: Fort Nehalem Publishing, 2011), Appendix 1, 161-93.

25. They concluded, "There are still many more stones whose location is currently unknown ... We believe that due to ... our ability to recreate Costaggini's survey ... we were able to find the locations of the stones that we were searching for. If given more time we believe that one could find evidence of at least some of the cairns" Peter Seaders and Beth Peutz, "2 Papers concerning the theorized Francis Drake 16th century survey on Neahkahnie Mountain, Oregon. Discussion 
and Review of Phillip A. Costaggini's Project on Neahkahnie Mountain, Oregon," Corvallis, Ore.: Submitted as an Oregon State Civil Engineering Project, 2008, www.academia.edu: https://www.academia.edu/25590840/2_Papers_concerning_the_theorized_Francis_ Drake_16th_century_survey_on_Neahkahnie_Mountain_Oregon (accessed May 16, 2018).

26. Ibid.

27. Dennis Griffin, "The Evolution of Oregon's Cultural Resource Laws and Regulations," Journal of Northwest Anthropology 43:1 (Spring 2009): 92

28. Ibid., 92-93.

29. Ibid., 93

30. Dennis Griffin, "A History of Underwater Archaeological Research in Oregon," Journal of Northwest Anthropology 47:1 (Spring 2013): 3.

31. Ibid, 3-4; the law is ORS 358.905 (c)

32. Ibid, 4-5.

33. Griffin, "The Evolution of Oregon's Cultural Resource Laws and Regulations," 93-94.

34. ORS 273.718-273.742. Representative Anunsen introduced HB 1321 in 1967 that created the Treasure Trove Act. The bill was titled "Relating to the removal of material from state lands; and declaring an emergency." On the bill passing it was added to the larger group of 273.705-711 statutes titled "Removal of Historical and other Valuable Materials" and assigned ORS 273.715 titled "Rules for removal of treasure-trove, semiprecious stones and petrified wood from state lands; removal contrary to rules."

35. Griffin, "The Evolution of Oregon's Cultural Resource Laws and Regulations," 95. This article incorrectly identifies the 1967 law as first containing a definition of Treasure Trove. The 1973 law that first defined "treasure trove" was introduced in the Legislature as SB 609.

36. The Oregon Highway Department became the Highway Division of the newly created Oregon Department of Transportation (ODOT) in 1969, as did the Parks Division, which had been part of the Highway Department when it was a separate entity. For a full history of Oregon transportation system and governing agencies, see Oregon on the Move:
A history of Oregon's transportation systems. ODOT History Committee (undated), http:// www.oregon.gov/ODOT/About/Documents/oregononmove_final.pdf (accessed May 6, 2018).

37. Griffin, "The Evolution of Oregon's Cultural Resource Laws and Regulations," 95

38. Griffin, "There's Gold on Them Thar Beaches or Searching for Treasure in All the Wrong Places," 4-5.

39. "Astorian to Salvage Ship: Spit Sands Hids [sic] Treasure Craft for Centuries," Wheeler Reporter (August 1, 1929), in Geisecke, Beeswax, Teak and Castaways, 29.

40. William S. Cox, Director of DSL, to David R. Clark, February 13, 1979 and February 21, 1979 (in Treasure Trove Box \#1, 'David Clark' file, Oregon SHPO.

41. State Land Board Agenda, Item \#5, "Application for Treasure Trove Permit, Nehalem Bay bed, about 1 mile from the mouth," April 11, 1979 (in 'Treasure Trove Box \#2, 'Treasure Trove TAC Notes, Land Board Agendas, Background Info' file, Oregon SHPO).

42. "Application for Treasure Trove Permit" [undated] of James McCanna, received by DSL December 31, 1986, (in Treasure Trove Box \#1, 'James McCanna Permit' file, Oregon SHPO).

43. "Application for Treasure Trove Permit" of Delmar Wagner and Forrest Rigger, received by DSL October 26, 1989 (in Treasure Trove Box \#1, 'Wagner and Rigger' file, Oregon SHPO).

44. See Treasure Trove Box \#1, 'Bill Warren' file, stored at Oregon SHPO.

45. Martha Pagel, Director of DSL, letter to William Warren, May 18, 1989; Janet Neuman, Assistant Director of DSL, letter to William Warren, March 22, 1989; and Leland Gilsen, SHPO archaeologist, to James Barlow, August 31, 1988 (in Treasure Trove Box \#1, 'Bill Warren' file, Oregon SHPO).

46. Sinclair Archaeological Services Incorporated. "Research Design for Archaeological Recovery of the Nehalem Wreck," 15, prepared for the San Francisco Xavier Corporation, 1989, on file at Oregon SHPO office.

47. "Notorious treasure hunter joins $\mathrm{Ne}$ halem search," Daily Astorian, June 7, 1989, p. 1; "Treasure hunter raises concerns," Tillamook Headlight-Herald, August 2, 1989, p. 1.

48. Lorraine Vandecoevering, letter to 
Janet Neuman Assistant DSL Director, July 16, 1990; and Janet Neuman, letter to Lorraine Vandecoevering, August 6, 1990 (in Treasure Trove Box \#1, 'Vandecoevering' file, Oregon SHPO).

49. Martha O. Pagel, DSL Director, letter to William Warren, March 17, 1989, (in Treasure Trove Box \#1, ‘Bill Warren' file, Oregon SHPO).

50. Bill Warren, letter to Gail Achterman, September 6, 1989, (in Treasure Trove Box \#1, 'Bill Warren' file, Oregon SHPO).

51. Leland Gilsen, SHPO, letter to James Barlow, DSL Minerals Leasing Manager, August 31, 1988 (in Treasure Trove Box \#1, 'Bill Warren' file, Oregon SHPO).

52. Paul Cleary, Director of Division of State Lands, letter to LaVerne Johnson, September 24, 1998; Donald Landes, Attorney, letter to Paul Cleary, October 6, 1998; Donald Landes, letter to Jenifer Robison, Special Assistant to the Director, Division of State Lands, October 28, 1998; Paul Cleary, letter to Donald Landes, November 16, 1998; Donald Landes, letter to Paul Cleary, December 3, 1998; Paul Cleary, letter to Don Landes, Dec. 23, 1998 (in Treasure Trove Box \#2, 'Treasure Trove TAC Notes, Land Board Agendas, Background Info' file, Oregon SHPO).

53. Donald Landes, letter to Paul Cleary, February 22, 1999 (in Treasure Trove Box \#2, 'Treasure Trove TAC Notes, Land Board Agendas, Background Info' file. Oregon SHPO); Leland Gilsen, SHPO Archaeologist, letter to Jennifer Robison, Re: Shipwreck Recovery, February 1, 1999 (in Treasure Trove Box \#2, 'Treasure Trove TAC Notes, Land Board Agendas, Background Info' file, Oregon SHPO).

54. C. Kent Roberts of Schwabe Williamson \& Wyatt, letter to Jennifer Robison, Re: LaVerne Johnson - Shipwreck Recovery Permit, February 23, 2000; William R. Cook, Assistant Attorney General, Natural Resources Section, letter to C. Kent Roberts, July 12, 2000, (in Treasure Trove Box \#2, 'Treasure Trove TAC Notes, Land Board' file, Oregon SHPO).

55. Hult, Lost Mines and Treasures of the Pacific Northwest, 40-41.

56. "Local writer has new twist on treasure," Tillamook Headlight-Herald, March 22, 1989, p. 1.

57. Rolla J. Crick, "Oregon Treasure Hunter Attracts Believers, Scoffers" Oregon
Journal, May 2, 1967, p. 1.

58. Mike Francis, "Treasure hunter's storm clouds gather," Oregonian, August 14, 1989, p. 1.

59. Application for Treasure Trove Permit of Tony Marino [sic] (in Treasure Trove Box \#1,'Tony Mareno' file, Oregon SHPO).

6o. Mike Francis, "Treasure hunter's storm clouds gather," Oregonian, August 14, 1989, p. 1.

61. "Neahkahnie Treasure Hunt No. 2, Viles and Jensen Party." Oregon State Highway Division Interdepartment Correspondence Memo, October 5, 1970. Curtis Baker, Recreation Staff Engineer, letter to David Talbot, State Parks Superintendent (in Treasure Trove Box \#1, 'Northwest Discoveries/Tillamook Treasures' file, Oregon SHPO).

62. Nehalem Valley Historical Society Treasure Committee, "Treasure Seekers: Orval Keller," in Tales of the Neahkahnie Treasure (Nehalem: Nehalem Valley Historical Society, 1991), 18-19.

63. Orval Keller, letter to Oregon State Highway Division, undated, rec'd October 29, 1971, (in Treasure Trove Box \#1, 'Orval Keller' file, Oregon SHPO).

64. R.L. Porter, State Highway Engineer, State Highway Division, letter to Orval Keller, November 4, 1971 (in Treasure Trove Box \#1, 'Orval Keller' file, Oregon SHPO).

65. David Talbot, State Parks Superintendent, letter to George Baldwin, Administrator of Highways, October 12, 1972 (in Treasure Trove Box \#1, 'Northwest Discoveries/Tillamook Treasures' file, stored at Oregon SHPO).

66. Curtis Baker, Recreation Staff Engineer, Interdepartment Correspondence Memo to File, "Neahkahnie Treasure Hunt," October 15, 1973 (in Treasure Trove Box \#1, 'Northwest Discoveries/Tillamook Treasures' file, Oregon SHPO).

67. Ibid.

68. Laurence R. Kittleman, Acting Director, Museum of Natural History, to Leonard G. Wilkerson, Land Specialist, Division of State Lands, February 10, 1974; William Cox, Director, Division of State Lands, letter to Mrs. Muriel Jackson, Assistant to the President, University of Oregon, January 23, 1974 (in Treasure Trove Box \#2, 'Neahkahnie Mountain' file, Oregon SHPO). 
69. John L. Fagan, Assistant Curator of Anthropology and Laurence R. Kittleman, Curator of Geology and Acting Director, Museum of Natural History, letter to Leonard G. Wilkerson, Land Specialist, Division of State Lands, March 26, 1974 (in Treasure Trove Box \#2, 'Neahkahanie Mountain' file, Oregon SHPO).

70. Lowell Grimes and Dean Grimes were related to one another, according to state documents. Dean ended his treasure-hunting career in about 1970, but Lowell continued on. Curtis Baker, Recreation Staff Engineer, Interdepartment Correspondence Memo to File, "Neahkahnie Treasure Hunt," October 15, 1973 (in Treasure Trove Box \#1, 'Northwest Discoveries/Tillamook Treasures' file, Oregon SHPO). Confusingly, Lowell's full name, Lowell Dean Grimes, led state and documents and news articles to often refer to Lowell Grimes as Dean Grimes. In addition, Lowell Grimes apparently often referred to himself as Dean Grimes, which official papers then reflected.

71. William Cox, Director, Division of State Lands, letters to Lowell Grimes, March 9, 1979 (in Treasure Trove Box \#1, 'Kretsinger/Grimes' file, Oregon SHPO).

72. William Cox, Director, Division of State Lands, letters to Lowell Grimes, March 30, 1979 (in Treasure Trove Box \#1, 'Kretsinger/Grimes' file, Oregon SHPO).

73. Leland Gilsen, Archaeologist, SHPO, to Lowell Grimes, April 16, 1979 (in Treasure Trove Box \#1, 'Kretsinger/Grimes' file, Oregon SHPO).

74. Lowell Dean Grimes to Leonard Wilkerson, DSL, March 10, 1979 (in Treasure Trove Box \#1, 'Kretsinger/Grimes' file, Oregon SHPO).

75. "Pat Edley, "Pair Seek Treasure In Shadow of Neah-Kah-Nie Mountain," Tillamook Headlight Herald, November 23, 1983, p. 1-4.

76. Ibid.

77. Ibid.

78. A. W. Johnstun, letter to Paul Hartwig, State Parks Historian, March 6, 1975, (in Treasure Trove Box \#1, 'Treasure Trove Miscellaneous' file, Oregon SHPO).

79. John S. Bergeson, letter to Division of State Lands, February 21, 1981 (in Treasure Trove Box \#1, 'Treasure Trove Miscellaneous' file, Oregon SHPO).
80. Leland Gilsen, SHPO Archaeologist, letter to Jan Haley, Dept. of State Lands, March 31, 1981 (in Treasure Trove Box \#1, 'Treasure Trove Miscellaneous' file, Oregon SHPO).

81. "Neahkahnie Mountain, Oregon Treasure Exploration Proposed Research Design for Test Excavations. Submitted to Leland Gilsen, State Historic Preservation Office, November 2, 1982" (in Treasure Trove Box \#1, 'TT Permits Grimes/Hughes' file, Oregon SHPO).

82. "Treasure Seekers: Ken Hughes" in Tales of the Neahkahnie Treasure. Prepared by the Nehalem Valley Historical Society Treasure Committee (Nehalem: Nehalem Valley Historical Society, 1991), 20-21.

83. Ibid, 3

84. Department of Justice "Opinion on ORS 273.705; ORS 273.718" to Stanley F. Hamilton, Resources Manager, Division of State Lands, April 18, 1983 (in Treasure Trove Box \#1, 'Kretsinger/Grimes' file, Oregon SHPO).

85. James Barlow, DSL Mineral Leasing Manager, to John N. Davis, October 5, 1989 , (in Treasure Trove Box \#1, 'John Davis/Corpus Land Investment' file, Oregon SHPO).

86. James Barlow DSL Mineral Leasing Manager, letters to John N. Davis, October 5 and October 24, 1989; Neil Goldschmidt, Governor, to John N. Davis, October 6, 1989; undated 1989 applications for Treasure Trove permit by John N. Davis/Corpus Land Investment (in Treasure Trove Box \#1, 'John Davis/ Corpus Land Investment' file, Oregon SHPO).

87. In 1999 there was a flurry of interoffice communication in the Parks and Recreation Department about a treasure seeker and her purported finds. See James Hamrick, Mike Stein and others, emails, September 23, 1999, and September 30, 1999 (in Treasure Trove Box \#2, 'AG Opinions' file, Oregon SHPO).

88. Dennis Griffin, State Archaeologist email to Cameron La Follette, December 31, 2017

89. Jennifer Robison, DSL memo to Paul Cleary, Subject: Treasure Trove. March 10, 1998 (in Treasure Trove Box \#2, untitled orange folder, Oregon SHPO).

90. Hult, Lost Mines and Treasures of the Pacific Northwest, 24.

91. Jan Fletcher, "Body found on beach may be that of missing treasure hunter," Or- 
egonian, June 27, 1990, p. 1.

92. Hult, Lost Mines and Treasures of the Pacific Northwest, 22-23, 39.

93. Nehalem Valley Historical Society Treasure Committee, Tales of the Neahkahnie Treasure, 8-10.

94. E.W. Geisecke, "Treasure of Neahkahnie: Gold in That Mountain," Oregon Journal, November 9, 1958, p. 1.

95. Anonymous, Tillamook HeadlightHerald, "Equipment Problem Slows Up NeahKah-Nie Treasure Quest," April 27, 1967; Rolla J. Crick, Oregon Journal, "Oregon Treasure Hunter Attracts Believers, Scoffers," May 2, 1967, p. 1; Oregon Journal [untitled article], September 7, 1967.

96. State Land Board, Minutes of March 15, 1968, RL-600-S, "In the matter of public hearing relative to Treasure Trove Permit"; and State Land Board, Minutes of May 24, 1968, RL6oo-S, "In the matter of request for treasure trove permit, Tillamook County," (in Treasure Trove Box \#2, 'Treasure Trove Miscellaneous' file Oregon SHPO).

97. R.L. Porter, State Highway Engineer, Oregon State Highway Division, letter to Orval Keller, November 4, 1971; R.L. Porter, letter to Senator Mark Hatfield, December 13, 1971, (in Treasure Trove Box \#1, 'Orval Keller' file, Oregon SHPO).

98. State Land Board Minutes of August 1974, In the Matter of a request by Paul Wolf for Treasure Trove permit; and Leonard G. Willkerson, Mineral Leasing Specialist, Division of State Lands, letter to Paul Wolf, October 14, 1974, (in Treasure Trove Box \#1, 'Paul Wolf' file, Oregon SHPO).

99. William Cox, Director, Division of State Lands, letter to George Celesnik, November 1, 1979, (in Treasure Trove Box \# 2, 'Treasure Trove Miscellaneous' file, Oregon SHPO).

100. Stan Hamilton, Division of State Lands Memorandum to Ed Zajonc, May 20, 1983, Subject 'Treasure Hunters Permit,' (in Treasure Trove Box \#1, in 'Kretsinger-Grimes' file, Oregon SHPO).

101. D.L. Walker, Region II Supervisor Interoffice Memo to Ed Kornblum, Manager, Cape Lookout State Park. Subject: Backhoe Illegally Digging on Elk Flats, Oswald West
State Park, 8/14/83; R.M. Caldwell, Trooper, Information Report, Dept of State Police, Criminal Mischief Investigation, Oregon State Parks, 8/14/83; Cary Huckaby, Park Foreman I, Interoffice Memo to Ed Kornblum, Manager, Cape Lookout State Park. Subject: Nonassessable Damages to Natural Environment in Vicinity of Neahkahnie Mountain Excavation Site, August 18, 1983 (in Treasure Trove Box \#1, 'Kretsinger-Grimes' file, Oregon SHPO).

102. Donald Mitchell, Land Resources Specialist, Division of State Lands, letter to Edwin Kretsinger and Lowell Grimes, Sept. 14, 1983; Larry Jacobson, Deputy State Parks Administrator, letter to Edwin Kretsinger and Lowell Grimes, August 31, 1983, (in Treasure Trove Box \#1, 'Kretsinger-Grimes' file, Oregon SHPO).

103. Division of State Lands Internal Memorandum, February 17, 1988, (in Treasure Trove Box \#1, 'Tony Mareno' file, Oregon SHPO).

104. Don Bischoff, "Fire Still Burns for Doubloons," Eugene Register-Guard, August 16, 1989; Mike Francis, "Treasure hunter's storm clouds gather." Oregonian, August 14, 1989; David Talbot, State Parks Administrator, letter to Dennis Messoline, April 14, 1989, (in Treasure Trove Box \#1, "Tony Mareno" file, Oregon SHPO).

105. Peter Bond, Beaches and Trails Coordinator, Parks and Recreation Division, letter to James Barlow, Minerals Leasing Manager, Division of State Lands, June 19, 1989, Re: Edward M. Fire, Treasure Trove Application. [In Treasure Trove Box \#1, 'Ed Fire Manzanita Beach' file, Oregon SHPO).

106. Pat Forgey, "Law review may halt searches for treasure," Daily Astorian, August 23, 1989, p. 1.

107. Douglas Deur, emails to Cameron La Follette, June 2, 2015; Mike Stein, North Coast District Manager, OPRD Coastal Region, emails to Cameron La Follette, June 9, 2015; Mike Stein, email to Cameron La Follette, June 12, 2015.

108. Leonard Wilkerson, DSL Memorandum to William Cox, Subject: "Discussion of semi-precious stone, petrified wood, lost goods and money and treasure trove program frustrations." Sept. 28, 1973, (in Treasure Trove Box 
\#2, 'Treasure Trove Rules' file, Oregon SHPO). 109. Griffin, "There's Gold on Them Thar Beaches or Searching for Treasure in All the Wrong Places," 5-6.

110. Ibid., 5.

111. Griffin, Treasure Trove Permit Table. On file at SHPO office, Salem, OR.

112. Division of State Lands, Notice of Proposed Rulemaking, June 3, 1988, concerning ORS 273.722, (in Treasure Trove Box \#2, 'Repeal of Treasure Trove Rules' file, Oregon SHPO).

113. David Talbot, State Parks Administrator, letter to Dennis Messoline, April 14, 1989, (in Treasure Trove Box \#1, 'Tony Mareno' file, Oregon SHPO).

114. Pat Fogarty, "Land Board halts treasure hunting permits," Daily Astorian, Undated, probably 1989, p. 1; Carl Anderson, "Treasure seekers hot on trail again," Tillamook Headlight-Herald, November 14, 1990, p. 1..

115. Griffin, Treasure Trove Permit Table. On file at Oregon SHPO).

116. State Land Board Regular Meeting, Sept. 10, 1991, Agenda Item 6b, (in Treasure Trove Box \#2, 'Land Board' file, Oregon SHPO).

117. Summary Notes: Meeting on Treasure Trove, Repatriation Legislation, and Archaeological Permit Rule, Monday, May 4, 1992, (in Treasure Trove Box \#2, 'Treasure Trove Rules' file, Oregon SHPO).

118. DSL Interoffice Memo, February 6, 1998, Re: Options for Treasure Trove; DSL Interoffice Memo, February 2, 1998, Subject: Treasure Trove, (in Treasure Trove Box \#2, 'Treasure Trove TAC Notes, Land Board Agendas, Background Info' file, Oregon SHPO). Emphasis in original.

119. Treasure Trove Work Group Meeting Minutes, Wednesday, July 15, 1998, (In Treasure Trove Box\#2, 'Treasure Trove TAC Notes, Land Board Agendas, Background Info' file, Oregon SHPO).

120. State Land Board Regular Meeting, Agenda Item \# [unspecified], April 14, 1998, (in Treasure Trove Box \#2, 'Treasure Trove TAC Notes, Land Board Agendas, Background Info' file, Oregon SHPO).

121. Griffin, "The Evolution of Oregon's Cultural Resource Laws and Regulations," 95.

122. "Nuestra Señora de Atocha, Santa
Margarita, Spanish Galleons of 1622," 1622 Fleet, Mel Fisher Maritime Museum, http:// www.melfisher.org/1622.htm (accessed June 25, 2017).

123. State Land Board Regular Meeting October 10, 1989, Agenda Item 1; Dept. of Justice Opinion Request OP-6275 to Division of State Lands, October 14, 1988; and Dept. of Justice Opinion Request OP-6275-A to Division of State Lands, April 21, 1989, (in Treasure Trove Box \#2, 'Repeal of Treasure Trove Rules' file, Oregon SHPO).

124. Ian K. Whitlock, Letter Opinion to Robert Meinen, Director, SHPO, OPRD. DOJ File No. 634-900-GNo275-98, (in Treasure Trove Box \#2, Orange folder, Untitled file, Oregon SHPO).

125. The Confederated Tribes of the Umatilla Indian Reservation, the Confederated Tribes of the Siletz Indians, the Coquille Indian Tribes, the Confederated Tribes of the Grand Ronde and the Confederated Tribes of the Warm Springs, all favored outright repeal of the Treasure Trove statute and mentioned the increased protection of archaeological and historic sites that would result from clarifying the need to protect cultural resources. [Letters to State Land Board from Confederated Tribes of the Umatilla Indian Reservation (July 8, 1998), Confederated Tribes of Siletz Indians (July 8, 1998), Coquille Indian Tribe (July 1, 1998), Confederated Tribes of the Grand Ronde Community (July 9, 1998), and Confederated Tribes of Warm Springs (July 9, 1998), (in Treasure Trove Box \#2, 'Treasure Trove-LC Working Group' file, Oregon SHPO).

126. Quinn Bender, "Mystery of Manzanita's Mountain" [undated] http://quinnbender. com/manzanita (accessed August 6, 2017); John Terry, "Mystery of treasure, pirates, lingers for centuries at Neahkahnie Mountain," Oregonian, February 7, 2010; Finn D. John, "The Legendary Spanish Gold of Neahkahnie Mountain" Offbeat Oregon History, http:// www.offbeatoregon.com/H1008d_spanishgold-of-neahkahnie-mountain.html (accessed May 18, 2018); Griffin, "Griffin, "The Evolution of Oregon's Cultural Resource Laws and Regulations," 95. 